\title{
Longwall top coal caving design for thick coal seam in very poor strength surrounding strata
}

\author{
H. Jangara ${ }^{1}$ - C. Atilla Ozturk ${ }^{1}$
}

Received: 14 July 2020/Revised: 7 October 2020/Accepted: 18 December 2020/Published online: 1 February 2021

(C) The Author(s) 2021

\begin{abstract}
Alpu lignite field is an important coal deposit with nearly 2 billion tons of coal resources located in the middle of Turkey. The mine deposit consists of three main seams. The thickness of two of them vary from 4 to $30 \mathrm{~m}$. The surrounding rock mass is very poor in terms of strength. The high clay content and weak rock mass make mechanized mining difficult. In this research, applicability of the longwall top coal caving method was investigated. The very weak strength behavior of the coal and the surrounding strata increases the importance of research in the mine site in terms of ground control. The aim is to design the mechanized longwall mine based on ground control principles. First of all, classification of the roof, coal, inter-burden, and floor strata were classified based on geotechnical aspects. Then, cavability index, shield, and floor bearing capacity were investigated. Different methods were applied to understand the limitations of a mechanized system that is very critical due to the very low strength strata. According to the main results, roof strata was classified as immediately caving while mining height was calculated as 5-6 m. Finally, the relations among geotechnical characterizations of roof and floor strata, cutting and caving heights, and required shield capacity were presented based on analytical and numerical applications. The proposed approach can be used as a ground control method for the applicability as well as the limitations of mechanized longwall mining design in weak strata conditions.
\end{abstract}

Keywords Coal $\cdot$ Geotechnics $\cdot$ Ground control $\cdot$ Longwall mining $\cdot$ Numerical methods

\section{Introduction}

Longwall mining is one of the most applicable and effective production methods for underground coalmines. Longwall mining is attractive for producers due to its high production rate (Galvin 2016). Mechanized longwall mining requires heavy machinery and equipment that are shearer for coal cutting, hydraulic shields for roof control, and armored face conveyor (AFC) for the haulage of the coal. The mechanized longwall mining requires flat-lying coal seams, in which the dip of the seam should not be more than $20^{\circ}$. The amount of coal for the production panel

C. Atilla Ozturk

atilla.ozturk@itu.edu.tr

$1 \quad$ Mining Engineering Department, Faculty of Mines, Istanbul Technical University, Istanbul, Turkey must be high enough to cover the initial investment of the mechanized longwall system. Longwall top coal caving (LTCC) is a part of longwall mining that is applicable for thick coal seams. China is an important country, which has best practices of LTCC in terms of high production rates. The production principle of LTCC is similar to the conventional longwall mining; however, there are two conveyors named as front and rear, which are used to haul the broken coal cut by shearer and the caved coal from the rear of the hydraulic systems, respectively (Alehossein and Poulsen 2010). A schematic view of a typical LTCC practice is presented in Fig. 1. Wang (2014) reviewed the status of fully mechanized mining technology in detail for China especially for thick coal seams. It was outlined that the one of the key issue of the mechanized mining defined as complex geological conditions. Wang and Pang (2017) also presented longwall technology for the interaction 


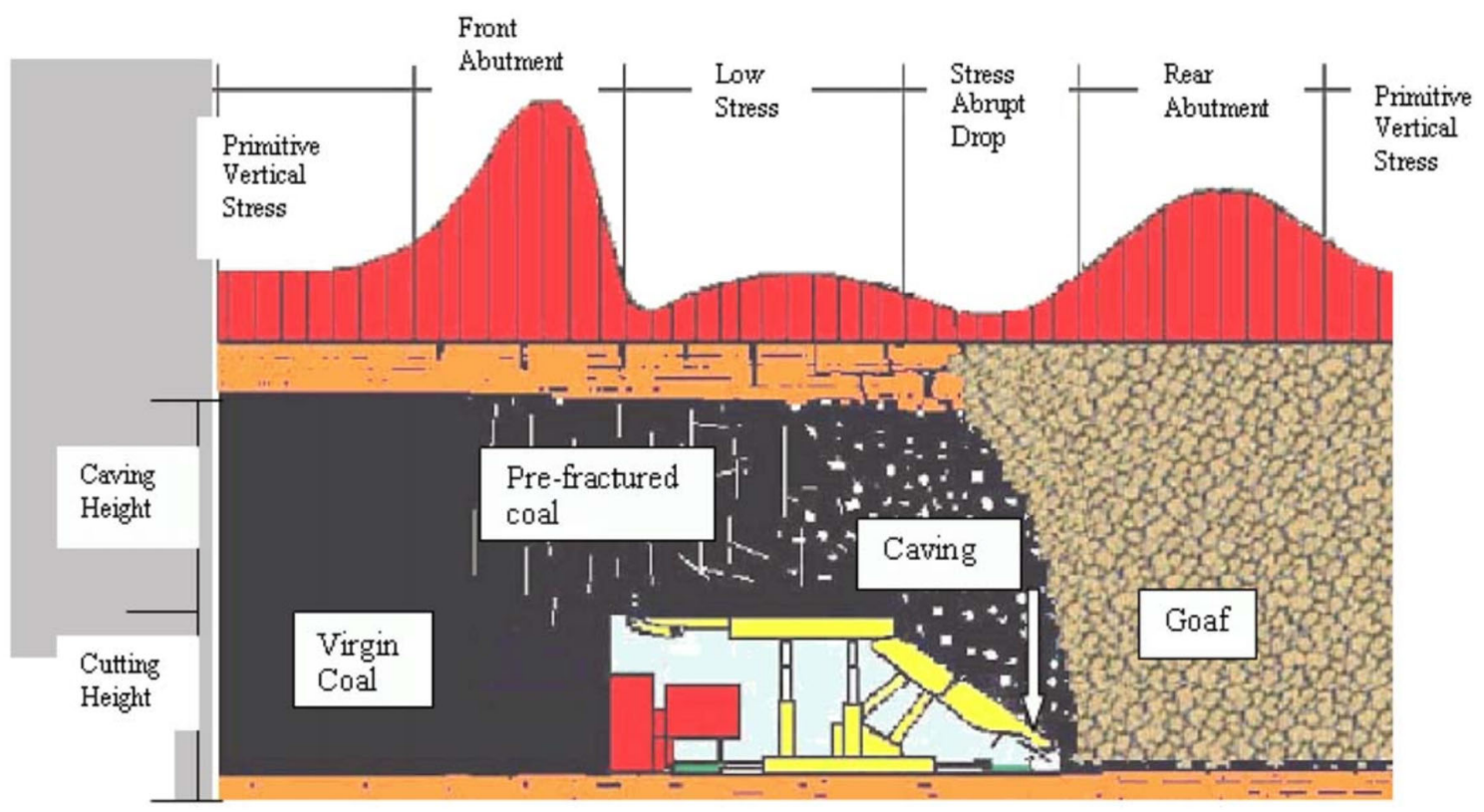

Fig. 1 LTCC method (Alehossein and Poulsen 2010)

between hydraulic supports and surrounding rock mass properties. Face advance rate which is also very critical for mechanized longwall mine stability and scheduling has been also investigated as a part of ground control issues for fully mechanized mining (Aghababaei et al. 2019).

Fully mechanized LTCC mining method is a good recovery for ultra-thick coal seams especially seams above $7 \mathrm{~m}$. Developing technologies increases the recovery rate for LTCC more than working in slice panels (Wang et al. 2015). Different drawing alternatives effect the recovery rate of the top coal as also outlined by Wang et al. (2015), and it proposed that one cutting and one drawing working methodology leads to increase the top coal recovery. However, the low strength behavior in terms of geotechnical properties of floor and roof strata leads to decrease the top coal recovery due to the limit of the longwall working height. The relation between the productivity of coal seam based on geotechnical properties investigated in the study that is the key factor for the recovery of top coal.

Strata movement in longwall mining is generally well described and classified in a caved zone that is behave as an immediate roof. The height of the caved zone is described by the bulking factor, which is the ratio of broken rocks volume to intact rocks (Peng 2008). Overburden strata was categorized into four zones as (1) caved, (2) fractures, (3) continuous deformation, and (4) soil zone from seam to the surface (Syd 1992). Peng and Chiang (1982) categorized the immediate roof in three classes, which are unstable, medium, and stable. Peng (2019) also described the immediate and main roof heights in detail. Ground control is not only related to the stability of openings, but it is also interested in floor bearing capacity, pillar design, shield design, and subsidence. The overlying strata is left as a block when the immediate roof is caved. Required shield capacity can be determined from the gravity forces applied by the separated block that depends on the immediate roof bulking factor (Barczak and Tadolini 2006). Ofoegbu et al. (2008) summarized the researches related to the bulking factor in coal mines around the world.

Ground control principles have developed mostly in coal mines due to the weak strength behavior of coal and surrounding strata in Turkey. Alpu coal mine deposit is a virgin lignite field having nearly two billion tons of coal. The mine site is divided into the different sectors and prefeasibility studies have been carried out individually since 2014. There are plenty of scope and feasibility studies have conducted for the site and the geotechnical investigations have shown that the geotechnical features of coal and the surrounding rock mass are the weakest link in the chain. Although the Turkish coal mining industry gets accustomed to working in low and fair strength strata, the initial results of the geotechnical investigations indicate that not only coal itself but also surrounding strata are critical in terms of strength due to its low and very low strength definitions. The study aims to investigate the applicability of LTCC as a mechanized underground production method. Caving behavior was simulated for required shield capacity investigations. In addition, floor bearing capacity was researched for the hydraulic shields and AFC designs. Analytical and numerical methods were also performed in this study for the design of LTCC in thick coal seam that is seam-A. Furthermore, application of conventional 
mechanized longwall mining was investigated for seam-C as an auxiliary purpose of the study.

\section{Brief geology of the mine site}

Alpu lignite mine is located in the middle of Turkey and it is approximately $14 \mathrm{~km}$ east of Eskisehir province, and $3 \mathrm{~km}$ northwest of Ankara Eskisehir main road. The license area of Esan Company, nearly having 15\% of Alpu lignite resource, is approximately $24 \mathrm{~km}^{2}$. The longest distance from north to south is $5 \mathrm{~km}$ and from east to west is $6 \mathrm{~km}$.

Turkey coal deposits mostly took shape during the carboniferous and tertiary periods. Alpu lignite mine site is located in Sakarya terrane and Anatolide tauride block, which is separated by the Intra-pontide suture zone passing through the Bozuyuk-Eskisehir line (Toprak et al. 2015).

The basement rocks of the basin are formed by Paleozoic metamorphic rocks and Mesozoic ophiolites. At the north of the basin, the metamorphic rocks, which contain marbles and blue schists, are overlaid by the ophiolites. The ophiolitic mélange is formed by radiolarites, radiolarian limestones, mudstones, serpentines, diabase, limestone, schist blocks, partly serpentinized peridotite, and partly metamorphosed diabase and gabbro. Chalcopyrite, malachite and pyrite mineralization and quartz veins are monitored through the faults and cracks inside the ophiolitic rocks. Neogene deposits inappropriately overlay the basement rocks (Asutay et al. 1989). A geological map and a cross-section are given in Figs. 2 and 3, respectively.

The quality of lignite was investigated previously by Turkey General Directorate of mineral research and exploration (MTA) and the results show that calorific value varies between $1500 \mathrm{kcal} / \mathrm{kg}$ and $3000 \mathrm{kcal} / \mathrm{kg}$ with the $2050 \mathrm{kcal} / \mathrm{kg}$ average. The average values for moisture content, ash, volatile matter, fixed carbon, and sulphur are $34 \%, 32 \%, 21 \%, 13 \%$, and $1.5 \%$, successively (Senguler 2013).

Alpu lignite field consists of three main seams named as seam-A, seam-B, and seam-C according to the exploration study. The thickness of the seams varies between 10 and $30 \mathrm{~m}$ for seam-A, $0.5-1.5 \mathrm{~m}$ for seam-B, and $2-4 \mathrm{~m}$ for seam-C. Seams are located in $205-450 \mathrm{~m}$ depth. It was decided that LTCC is designed as the mechanized longwall mining method for seam-A while conventional mechanized longwall mining method is selected for seam-C.

\section{Geotechnical investigations for the mine site}

Geotechnical classification of coal and surrounding rock masses are performed as the first step of geotechnical database construction. Four numbers of geotechnical boreholes were used to proceed with rock mechanics works. First of all, materials were categorized as soil and rock. If the materials' strength is less than $1 \mathrm{MPa}$, that is defined as soil and a different procedure applied for

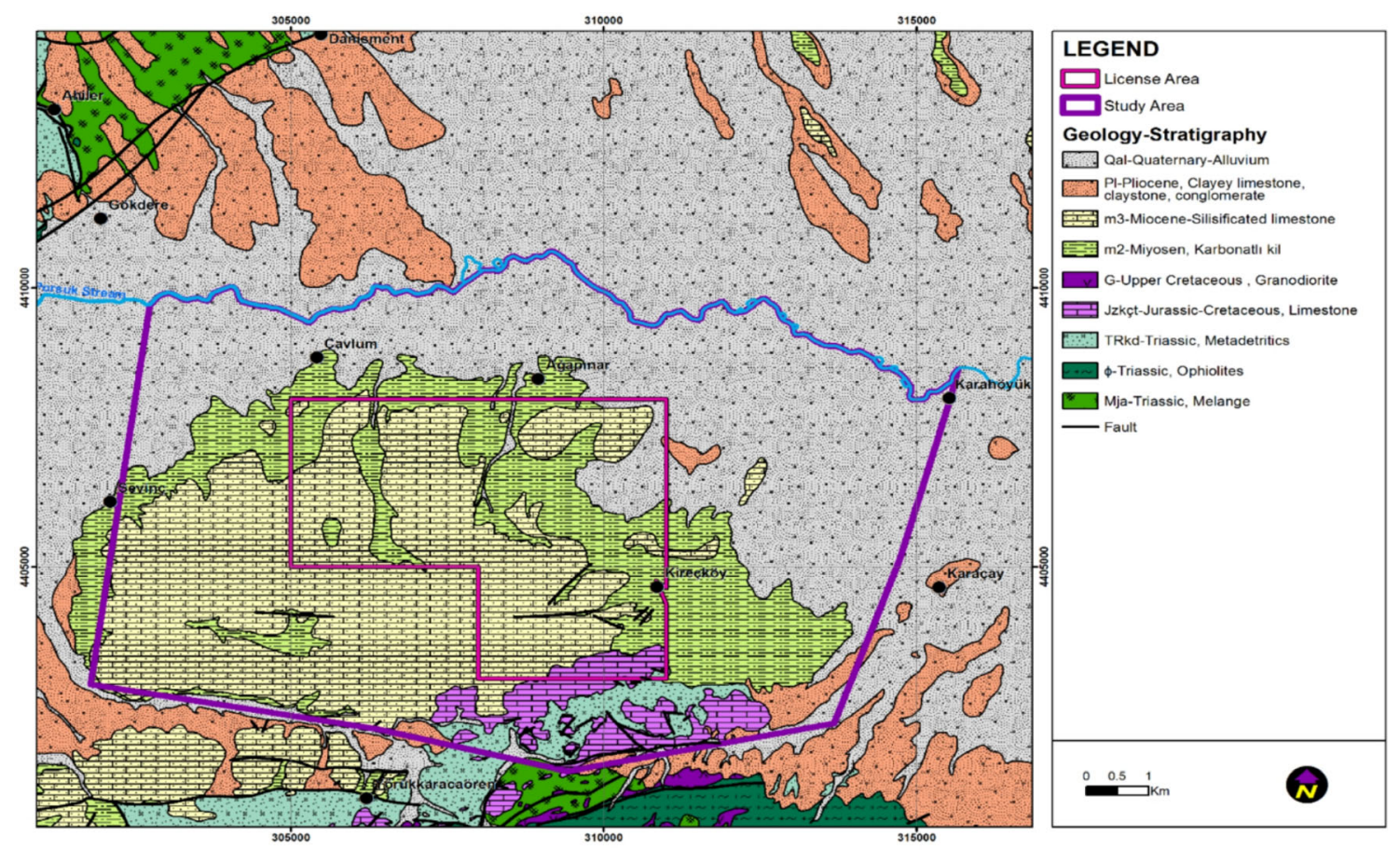

Fig. 2 Geological map of the study area (Yazicigil 2016) 


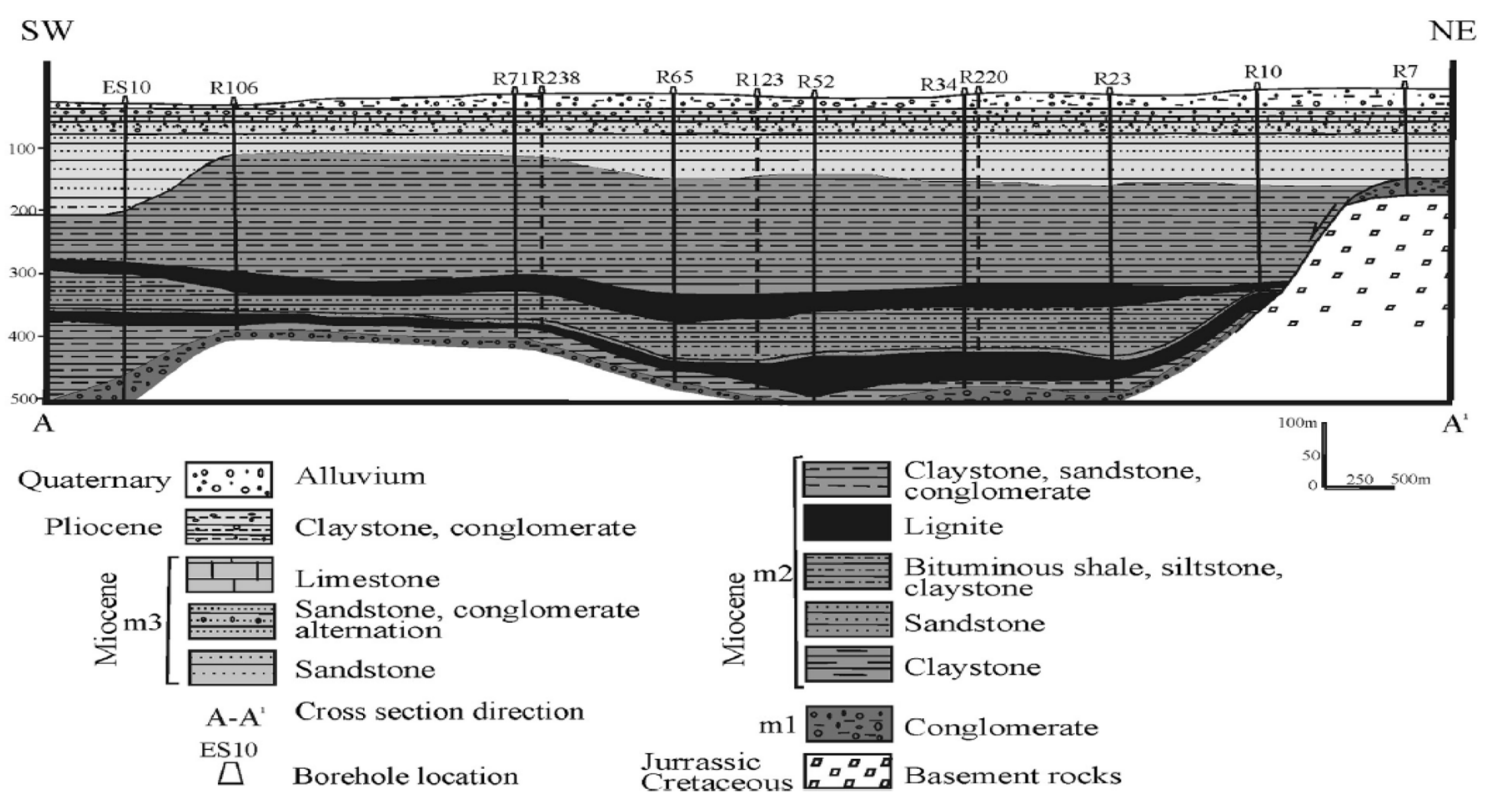

Fig. 3 Geological cross-section (Senguler 2013)

sampling during the drilling works. Then, soil samples were taken as undisturbed while rock samples were determined separately. The general layout for geotechnical classification of coal and surrounding strata based on lithology and location of the material according to the coal seams were presented in Table 1 . Intact rock and rock mass properties were then quantified from the site and the laboratory studies.

\subsection{Intact rock and soil quantification}

Mechanical and physical properties of the soil and the rock were determined from a series of laboratory tests. Uniaxial and triaxial compression tests, indirect tensile tests, slake durability tests, and physical properties determination tests were applied to the rock samples. Sieve analyses, unconfined compression and undrained unconsolidated triaxial, and direct shear tests were applied to the soil samples.

Uniaxial compressive strength, modulus of elasticity, Poisson's ratio, cohesion, internal friction angle, and Brazilian tensile strength were determined as mechanical properties of intact rock. The average values of the test results are presented in Table 2 . Physical properties and slake durability index values can be seen in Table 3 .

The results are quite interesting due to its very low values. All materials apart from the geotechnical classifications are in very low strength. Materials were dispersed in water during physical tests except for roof claystone of seam-A and lignite of seam-B. Floor claystone for both seam-A and seam-B are very sensitive to water according

Table 1 The general layout of lignite seams and surrounding strata

\begin{tabular}{llll}
\hline Geotechnical classification & Lithology & Abbreviations & Material type \\
\hline Seam A roof claystone & Clay and claystone & SAR & Rock and soil \\
Seam A & Lignite & SA & Rock \\
Seam A intermediate & Clay and claystone & SAI & Rock and soil \\
Seam A floor claystone & Clay and claystone & SAF & Rock and soil \\
Roof shale & Shale & RSha & Rock \\
Seam B & Lignite & SB & Rock \\
Floor shale & Shale & FSha & Rock \\
Sandstone & Sandstone & SS & Rock and soil \\
Seam C roof claystone & Claystone & SCR & Rock \\
Seam C & Lignite & SC & Rock \\
Seam C floor claystone & Clay and claystone & SCF & Rock and soil \\
\hline
\end{tabular}


Table 2 Average mechanical properties of intact rock based on geotechnical classifications (Jangara 2017)

\begin{tabular}{|c|c|c|c|c|c|c|}
\hline Definition & $\begin{array}{l}\text { Cohesion } \\
(\mathrm{MPa})\end{array}$ & $\begin{array}{l}\text { Internal friction } \\
\text { angle }\left({ }^{\circ}\right)\end{array}$ & $\begin{array}{l}\text { Brazilian tensile } \\
\text { strength (MPa) }\end{array}$ & $\begin{array}{l}\text { Uniaxial compressive } \\
\text { strength (MPa) }\end{array}$ & $\begin{array}{l}\text { Elastic } \\
\text { modulus (MPa) }\end{array}$ & $\begin{array}{l}\text { Poisson's } \\
\text { ratio }\end{array}$ \\
\hline SAR claystone & 0.64 & 43.3 & 0.54 & 1.5 & 265 & 0.28 \\
\hline SA lignite & 0.90 & 29.9 & 0.28 & 3.4 & 583 & 0.25 \\
\hline $\begin{array}{l}\text { SA } \\
\quad \text { intermediate }\end{array}$ & 0.11 & 18.9 & 0.21 & 1.8 & 200 & 0.18 \\
\hline SAF claystone & 0.20 & 44.0 & 0.28 & 5.5 & 1377 & 0.24 \\
\hline SB shale & 1.76 & 30.1 & 1.22 & 5.7 & 364 & 0.19 \\
\hline SB lignite & 0.90 & 29.9 & 1.17 & 8.8 & 678 & 0.33 \\
\hline Sandstone & 1.11 & 38.6 & 0.32 & 3.8 & 998 & 0.34 \\
\hline SCR claystone & - & - & 0.30 & 2.2 & 566 & 0.35 \\
\hline SC lignite & 0.90 & 29.9 & 0.87 & 5.8 & 551 & 0.26 \\
\hline SCF claystone & 0.00 & 21.4 & 1.15 & 5.1 & 1384 & 0.26 \\
\hline
\end{tabular}

Table 3 Average physical properties of intact rock based on geotechnical classifications (Jangara 2017)

\begin{tabular}{|c|c|c|c|c|c|c|c|}
\hline \multirow[t]{2}{*}{ Definition } & \multirow{2}{*}{$\begin{array}{l}\text { Unit volume } \\
\text { weight } \\
\left(\mathrm{kN} / \mathrm{m}^{3}\right)\end{array}$} & \multirow{2}{*}{$\begin{array}{l}\text { Slake Durability } \\
\text { Index }\left(I_{\mathrm{d} 2}\right) \\
(\%)\end{array}$} & \multicolumn{2}{|c|}{ Slake Durability Classification } & \multirow{2}{*}{$\begin{array}{l}\text { Porosity } \\
(\%)\end{array}$} & \multirow{2}{*}{$\begin{array}{l}\text { Water content } \\
(\%)\end{array}$} & \multirow{2}{*}{$\begin{array}{l}\text { Water } \\
\text { absorption (\%) }\end{array}$} \\
\hline & & & $\begin{array}{l}\text { ASTM D } \\
4644\end{array}$ & Gamble (1971) & & & \\
\hline $\begin{array}{l}\text { Seam A roof } \\
\text { claystone }\end{array}$ & 20.04 & 74.03 & $\begin{array}{l}\text { Type } 2 \text { and } \\
3\end{array}$ & Medium & 26.50 & 17.96 & 13.83 \\
\hline Seam A & 15.20 & - & - & - & \multicolumn{2}{|c|}{ Samples dispersed in water } & \\
\hline $\begin{array}{l}\text { Seam A } \\
\quad \text { intermediate }\end{array}$ & 14.82 & 55.23 & $\begin{array}{l}\text { Type } 2 \text { and } \\
3\end{array}$ & Medium to low & \multicolumn{2}{|c|}{ Samples dispersed in water } & \\
\hline $\begin{array}{l}\text { Seam A floor } \\
\text { claystone }\end{array}$ & 20.41 & 46.10 & $\begin{array}{l}\text { Type } 1 \text { and } \\
2\end{array}$ & Very low to High & \multicolumn{2}{|c|}{ Samples dispersed in water } & \\
\hline Shale & 13.56 & 91.74 & $\begin{array}{l}\text { Type } 1 \text { and } \\
2\end{array}$ & $\begin{array}{l}\text { Medium to Very } \\
\text { High }\end{array}$ & \multicolumn{2}{|c|}{ Samples dispersed in water } & \\
\hline Seam B & 13.66 & - & - & - & 32.19 & 11.04 & 23.79 \\
\hline Sandstone & 21.81 & 41.35 & $\begin{array}{l}\text { Type } 1 \text { and } \\
3\end{array}$ & $\begin{array}{l}\text { Medium to very } \\
\text { low }\end{array}$ & \multicolumn{2}{|c|}{ Samples dispersed in water } & \\
\hline $\begin{array}{l}\text { Seam C roof } \\
\text { claystone }\end{array}$ & 20.96 & - & - & - & \multicolumn{2}{|c|}{ Samples dispersed in water } & \\
\hline Seam C & 13.11 & - & - & - & \multicolumn{2}{|c|}{ Samples dispersed in water } & \\
\hline $\begin{array}{l}\text { Seam C floor } \\
\text { claystone }\end{array}$ & 21.53 & 34.05 & $\begin{array}{l}\text { Type } 2 \text { and } \\
3\end{array}$ & Low to very low & \multicolumn{2}{|c|}{ Samples dispersed in water } & \\
\hline
\end{tabular}

to the slake durability test results. The strength properties of lignite in each seam are also in very poor qualities according to the mechanical and physical tests of intact rock.

Brief information can be found in Table 4 regarding soil mechanics tests. Soils are mostly found in clay content strata in the roof, intermediate zone, floors of seam-A, and seam-B. Some parts of sandstone also demonstrate soil properties. The results are critical especially for floor clay materials due to their high value of plasticity index that signalized swelling issues.

\subsection{Rock mass properties}

Rock mass properties are characterized by the rock mass rating system proposed by Bieniawski (1976). Required data determined from geotechnical boreholes are presented in Table 5. The average value of rating and calculated RMR are given for each rock mass in Table 6. 
Table 4 Average soil properties based on geotechnical classifications (Jangara 2017)

\begin{tabular}{|c|c|c|c|c|c|c|c|c|}
\hline Definition & $\begin{array}{l}\text { Natural water } \\
\text { content } \\
(\%)\end{array}$ & $\begin{array}{l}\text { Liquid } \\
\text { limit } \\
(\%)\end{array}$ & $\begin{array}{l}\text { Plastic } \\
\text { limit } \\
(\%)\end{array}$ & $\begin{array}{l}\text { Plasticity } \\
\text { index } \\
(\%)\end{array}$ & $\begin{array}{l}\text { Unified soil } \\
\text { classification system }\end{array}$ & $\begin{array}{l}\text { Unit weight } \\
\left(\mathrm{kN} / \mathrm{m}^{3}\right)\end{array}$ & $\begin{array}{l}\text { Internal friction } \\
\text { angle }\left({ }^{\circ}\right)\end{array}$ & $\begin{array}{l}\text { Cohesion } \\
(\mathrm{kPa})\end{array}$ \\
\hline SAR claystone & 29.2 & 72.2 & 29.4 & 43 & $\mathrm{CH}-\mathrm{MH}$ & 17.7 & 12.0 & 78.0 \\
\hline $\begin{array}{l}\text { SA } \\
\text { intermediate }\end{array}$ & 23.0 & 73.7 & 26.7 & 47 & $\mathrm{CH}$ & 18.6 & 23.2 & 57.3 \\
\hline $\begin{array}{l}\text { SAF } \\
\quad \text { Claytstone }\end{array}$ & 24.0 & 51.0 & 28.0 & 31 & $\mathrm{CH}$ & 17.0 & 15.0 & 32.0 \\
\hline Sandstone & 14.0 & 33.0 & 18.0 & 15 & $\mathrm{SC}$ & 20.3 & 45.0 & 111.0 \\
\hline SCF claystone & 22.8 & 71.8 & 26.8 & 45 & $\mathrm{CH}-\mathrm{SC}$ & 19.4 & 21.5 & 109.0 \\
\hline
\end{tabular}

Table 5 Average properties of rock masses (Jangara 2017)

\begin{tabular}{|c|c|c|c|c|c|c|c|c|}
\hline Definition & $\begin{array}{l}\mathrm{UCS} \\
(\mathrm{MPa})\end{array}$ & RQD & $\begin{array}{l}\text { Joint spacing } \\
(\mathrm{mm})\end{array}$ & Persistence & Separation & Roughness & Infilling & Weathering \\
\hline $\begin{array}{l}\text { SAR } \\
\text { claystone }\end{array}$ & 1.47 & 32.7 & 66.67 & $1-3 \mathrm{~m}$ & $0.1-10 \mathrm{~mm}$ & $\begin{array}{l}\text { Slightly } \\
\text { rough }\end{array}$ & $\begin{array}{l}\text { Soft } \\
\quad \text { filling }<5 \mathrm{~mm}\end{array}$ & Highly Weathered \\
\hline SA lignite & 3.43 & 29.7 & 94.67 & $1-3 \mathrm{~m}$ & $<0.1 \mathrm{~mm}$ & Smooth & None & $\begin{array}{l}\text { Moderately } \\
\text { weathered }\end{array}$ \\
\hline $\begin{array}{l}\text { SAF } \\
\text { claystone }\end{array}$ & 7.23 & 26.7 & 70.00 & $3-10 \mathrm{~m}$ & $0.1-10 \mathrm{~mm}$ & $\begin{array}{l}\text { Slightly } \\
\text { rough }\end{array}$ & $\begin{array}{l}\text { Soft } \\
\quad \text { filling }<5 \mathrm{~mm}\end{array}$ & Highly Weathered \\
\hline SB shale & 5.87 & 58.0 & 133.67 & $1-3 \mathrm{~m}$ & $<0.1 \mathrm{~mm}$ & $\begin{array}{l}\text { Slightly } \\
\text { rough }\end{array}$ & None & Slightly weathered \\
\hline SB lignite & 8.80 & 32.3 & 135.00 & $3-10 \mathrm{~m}$ & $<0.1 \mathrm{~mm}$ & $\begin{array}{l}\text { Slightly } \\
\text { rough }\end{array}$ & None & Slightly weathered \\
\hline SB shale & 5.87 & 46.3 & 103.00 & $1-3 \mathrm{~m}$ & $<0.1 \mathrm{~mm}$ & $\begin{array}{l}\text { Slightly } \\
\text { rough }\end{array}$ & None & Slightly weathered \\
\hline $\begin{array}{l}\text { SCR } \\
\text { claystone }\end{array}$ & 4.00 & 63.7 & 215.33 & $1-3 \mathrm{~m}$ & $<0.1 \mathrm{~mm}$ & $\begin{array}{l}\text { Slightly } \\
\text { rough }\end{array}$ & $\begin{array}{l}\text { Soft } \\
\quad \text { filling }<5 \mathrm{~mm}\end{array}$ & $\begin{array}{l}\text { Moderately } \\
\text { weathered }\end{array}$ \\
\hline Sandstone & 4.93 & 34.7 & 110.33 & $1-3 \mathrm{~m}$ & $0.1-10 \mathrm{~mm}$ & $\begin{array}{l}\text { Slightly } \\
\text { rough }\end{array}$ & $\begin{array}{l}\text { Soft } \\
\quad \text { filling }<5 \mathrm{~mm}\end{array}$ & Slightly weathered \\
\hline SC lignite & 1.77 & 16.0 & 87.67 & $3-10 \mathrm{~m}$ & $0.1-10 \mathrm{~mm}$ & $\begin{array}{l}\text { Slightly } \\
\text { rough }\end{array}$ & $\begin{array}{l}\text { Soft } \\
\quad \text { filling }<5 \mathrm{~mm}\end{array}$ & Slightly weathered \\
\hline $\begin{array}{l}\mathrm{SCF} \\
\text { claystone }\end{array}$ & 0.20 & 16.7 & 40.67 & $1-3 \mathrm{~m}$ & $0.1-10 \mathrm{~mm}$ & $\begin{array}{l}\text { Slightly } \\
\text { rough }\end{array}$ & $\begin{array}{l}\text { Soft } \\
\quad \text { filling }<5 \mathrm{~mm}\end{array}$ & $\begin{array}{l}\text { Moderately } \\
\text { weathered }\end{array}$ \\
\hline
\end{tabular}

Groundwater conditions assume as dripping for all rock masses. The results proved that the quality of rock masses are mostly classified as poor except for floor claystone of seam-A, roof claystone seam-C, seam-B, and sandstone in seam-C roof.

\section{Mechanized longwall mine design studies}

Geotechnical studies of lignite seams and surrounding strata present that the quality of the rock materials, soil materials and rock masses are very poor in strength. These results increase the importance of design studies for mechanized longwall systems. Caving behavior of roof strata, hydraulic shield working resistance, and required floor bearing capacity were investigated for the applicability of LTCC and conventional mechanized longwall mining systems. A LTCC was designed for two different alternatives in seam-A, and a conventional mechanized longwall system was designed for seam-C.

\subsection{Caving behavior of roof}

Beside the rock mass classification results which Seam-A and Seam-C roof materials are classified as poor and fair rock by RMR system (Table 6), rock quality index $(L)$ and 
Table 6 Average rating and RMR values for rock masses (Jangara 2017)

\begin{tabular}{|c|c|c|c|c|c|c|c|c|c|c|c|}
\hline Definition & $\begin{array}{l}\text { UCS } \\
(\mathrm{MPa})\end{array}$ & RQD & $\begin{array}{l}\text { Joint } \\
\text { spacing }\end{array}$ & Persistence & Separation & Roughness & Infilling & Weathering & Groundwater & RMR & $\begin{array}{l}\text { Rock mass } \\
\text { class }\end{array}$ \\
\hline $\begin{array}{l}\text { SAR } \\
\text { claystone }\end{array}$ & 0.7 & 6.3 & 7 & 2.7 & 4 & 3 & 2 & 1 & 4 & 30.7 & Poor rock \\
\hline SA lignite & 1 & 6.3 & 7 & 2.7 & 5 & 1 & 6 & 3 & 4 & 36 & Poor rock \\
\hline $\begin{array}{l}\text { SAF } \\
\text { claystone }\end{array}$ & 1.7 & 6.3 & 7 & 2 & 4 & 3 & 2 & 1 & 4 & 31 & Poor rock \\
\hline SB shale & 2 & 11.3 & 8 & 4 & 5 & 3 & 6 & 5 & 4 & 48.3 & Fair rock \\
\hline SB lignite & 2 & 6.3 & 7.7 & 2 & 4.7 & 3 & 6 & 5 & 4 & 40.7 & Poor rock \\
\hline SB shale & 2 & 9.7 & 8 & 4 & 5 & 3 & 6 & 5 & 4 & 46.7 & Fair rock \\
\hline Sandstone & 1.3 & 11.3 & 7 & 4 & 4.7 & 3 & 2 & 4.3 & 4 & 41.7 & Fair rock \\
\hline $\begin{array}{l}\text { SCR } \\
\text { claystone }\end{array}$ & 1 & 13 & 10 & 4 & 5 & 3 & 2 & 3 & 4 & 45 & Fair rock \\
\hline SC lignite & 1.7 & 4.7 & 8 & 2 & 4 & 3 & 3.3 & 5 & 4 & 35.7 & Poor rock \\
\hline $\begin{array}{l}\mathrm{SCF} \\
\text { claystone }\end{array}$ & 0.3 & 4.7 & 7 & 2.7 & 4 & 3 & 2 & 3 & 4 & 30.7 & Poor rock \\
\hline
\end{tabular}

coal mine roof rating (CMRR) were used to understand and characterize the caving behaviour of the roof strata. Rock quality index $(L)$ proposed by Bilinski and Konopko (1973) is used to classify roof caving behavior. $L$ is calculated by Eq. (1). $C$ is the compressive strength of roof rock while $K_{1}$ is the in situ strength coefficient, $K_{2}$ is the creep coefficient, and $K_{3}$ is the in situ water content coefficient. $K_{1}$ is taken as 0.33 for sandstone, 0.42 for mudstone, and 0.5 for claystone or siltstone. Similarly, $K_{2}$ can be assumed as 0.7 for sandstone and 0.6 for mudstone, claystone, or siltstone. Finally, $K_{3}$ is 0.6 for sandstone, 0.4 for claystone and mudstone with $50 \%$ relative humidity.

$L=0.0064 C^{1.7} K_{1} K_{2} K_{3}$

The condition of the longwall roof can be classified according to the value of $L$ (Mangal and Paul 2016). SeamA's roof, seam-A, and seam-C's roof classified and the average results of rock quality index and roof classification presented in Table 7. The results present the problematic behavior of roof strata for all conditions.
Apart from roof classification from the rock quality index, CMRR can also be used for a better understanding of the actual conditions. CMRR, which is used mostly for bedded coal measure rock, is currently applied for different purposes in mine planning such as longwall pillar design, roof support selection, and feasibility studies (Molinda et al. 2001).

Geotechnical borehole logging or underground face mapping can be used to gather required data for CMRR. Rating for the calculation of CMRR is well described by Mark and Molinda (2005) and the roof is classified in three ways that are weak, moderate, and strong. Laboratory test results and RQD values are used to obtain CMRR scores in Alpu lignite field.

Due to the low strength of the rock materials in any location of the lignite field, CMRR rating is taken as 5 for compressive strength. Rating for discontinuity spacing (DSR) is calculated by Eq. (2) from RQD. Finally, the overall rating is deducted due to the moisture sensitivity of the strata. Moisture sensitivity adjustment rating was determined from the slake durability index of the material.

Table 7 Roof strata classification based on rock quality index

\begin{tabular}{lllll}
\hline Definition & $L$ & Roof class & Description of roof strata & Allowable area of exposed roof \\
\hline SAR claystone & 0.08 & I & Very week, immediate fall of roof when exposed. Coal & Approx. 1 $\mathrm{m}^{2}$ \\
SA lignite & 0.40 & I & tops recommended for safety. Wet, stratified with & \\
SCR claystone & 0.02 & I & coal bands clay stone & \\
Sandstone & 0.62 & I & & \\
\hline
\end{tabular}


Table 8 CMRR of roof strata and seam-A

\begin{tabular}{|c|c|c|c|c|c|c|c|c|c|}
\hline \multirow[t]{2}{*}{ Definition } & \multicolumn{3}{|c|}{ Average values of } & \multicolumn{3}{|c|}{ Ratings for CMRR } & \multicolumn{2}{|c|}{ Average values for CMRR } & \multirow{2}{*}{$\begin{array}{l}\text { Roof } \\
\text { classification }\end{array}$} \\
\hline & $\begin{array}{l}\sigma_{\mathrm{c}} \\
(\mathrm{MPa})\end{array}$ & $\begin{array}{l}\text { RQD } \\
(\%)\end{array}$ & $\begin{array}{l}\text { Slake durability } \\
\text { index }(\%)\end{array}$ & $\begin{array}{l}\sigma_{\mathrm{c}} \\
(\mathrm{MPa})\end{array}$ & $\begin{array}{l}\text { Discontinuity } \\
\text { rating }\end{array}$ & $\begin{array}{l}\text { Moisture } \\
\text { sensitivity }\end{array}$ & $\begin{array}{l}\text { Without } \\
\text { moisture effect }\end{array}$ & $\begin{array}{l}\text { With moisture } \\
\text { effect }\end{array}$ & \\
\hline $\begin{array}{l}\text { SAR } \\
\text { claystone }\end{array}$ & 1.47 & 32.67 & 76.20 & 5.00 & 24.17 & -12.33 & 29.17 & 16.83 & Weak \\
\hline SA lignite & 3.43 & 29.67 & - & 5.00 & 22.97 & -7.00 & 27.97 & 20.97 & Weak \\
\hline SB shale & 5.87 & 46.33 & 92.60 & 5.00 & 28.57 & -4.33 & 33.57 & 29.23 & Weak \\
\hline Sandstone & 4.07 & 60.00 & 41.35 & 5.00 & 31.27 & -12.33 & 36.27 & 23.93 & Weak \\
\hline $\begin{array}{l}\text { SCR } \\
\text { claystone }\end{array}$ & 0.60 & 74.00 & - & 5.00 & 33.60 & -15.00 & 38.60 & 23.60 & Weak \\
\hline
\end{tabular}

Ratings and the results of the CMRR are presented in Table 8 . The results are similar to the rock quality index's results and roof strata is classified as weak in every type of the strata.

$\mathrm{DSR}=10.5$ In RQD -11.6

\subsection{Hydraulic shield support and floor bearing capacity for seam-A}

Top coal heights are generally three times higher than mining height. Some mines in China reached a successful geometry to increase mining height for LTCC (Wang et al. 2015). Similarly, the use of LTCC for dip angle's seams studied and drawing parameters proposed to improve top coal recovery (Wang et al. 2020). The only good side of the very poor surrounding rock strata condition for Alpu lignite field is the high cavability of the roof, which will be helpful for assumed LTCC method. On the other hand, weak materials in base reduce the bearing capacity of the floor, which can act as a limitation in work resistance of the hydraulic shield and mining height.

Wang et al. (2017) proposed three plies in top coal theory and categorized top coal as "granular ply", "bulk ply" and "cracked beam ply" based on the different fracture and caving features of a lower, middle, and upper ply of top coal in ultra-thick seam. However, in some conditions, there is only one ply or two plies, depending on the factors such as top coal's thickness, strength, fracture development, and crustal stress. The top coal portion in the study area is assumed as one-ply (granular ply) depending on the low strength of the lignite. The high cavability of the lignite seams reduces top coal thickness in the result of the low floor bearing capacity.

There are different methods that can be used to apply for hydraulic shield design such as detached roof block method, shield leg pressure measurement method, design of powered support selection model, and yielding foundation model. The existing geotechnical data allows applying detached roof block model for the study area, which is outlined in Fig. 4. The parameters used in the method are presented in Table 9, separately. The parameters used in the design studies are summarized in Table 10 that are determined from coal and surrounding strata geotechnical properties. Hydraulic shields' technical specifications can be seen in Table 11 that are collected from the machine and equipment specifications of hydraulic shields, AFC conveyor, and shearer are determined from the available equipment in mining industry.

The very poor strength of the roof and floor causes to search for different production alternatives. Three alternatives were performed in seam-A which are named as LTCC and sublevel production, LTCC and sublevel production with pillar, and sublevel conventional mechanized longwall mining. The alternatives are illustrated in Fig. 5.

The calculations performed to understand the availability of mining heights is the sum of cutting (mining) and top coal heights based on the bearing capacity of the floor. Available bearing capacity is taken as the average uniaxial compressive strength of the floor materials. It was taken as 3.4 MPa for coal and 5.5 MPa for seam-A floor claystone. The results were determined from the design studies, which are presented in Table 12.

In the second alternative, the upper part of seam-A that contains a lower calorific value (less than $1000 \mathrm{kcal} / \mathrm{kg}$ ) according to the exploration study leaves as a pillar. This helps to decrease the amount of weight in the immediate roof that also decreases the load on the hydraulic shield. The thickness of the pillar was assumed as $5 \mathrm{~m}$. The same calculation procedure was also applied for the second alternative and the results are presented in Table 13.

Finally, the third alternative was applied for the design of conventional mechanized longwall mining application in case of the unavailability of the LTCC method. The production will also be applied in sublevels. In other words, slices and the production are only performed in advance instead of the top coal. Different mining heights were 

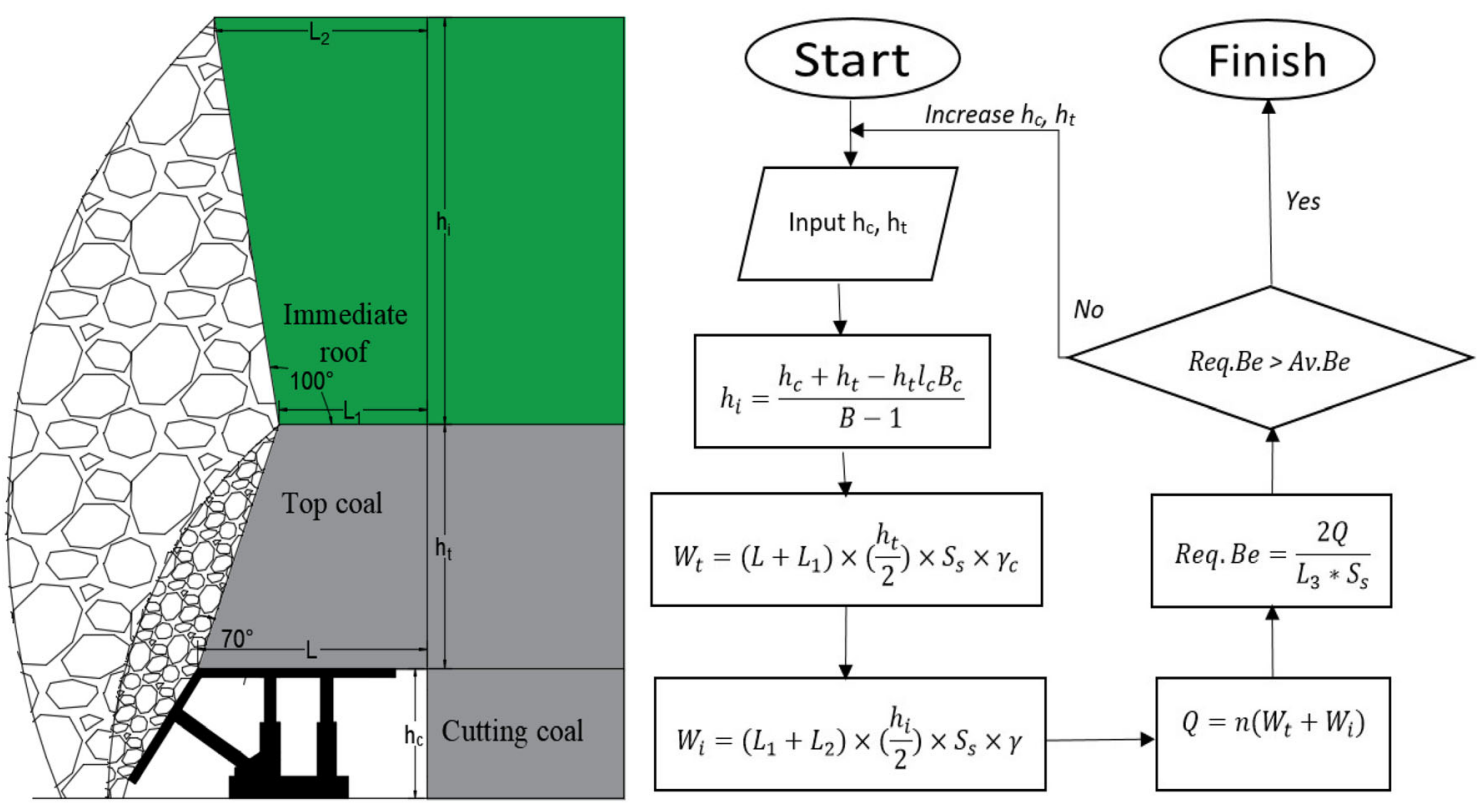

Fig. 4 Detached block method application parameters and rules (Jangara et al. 2018) a LTCC and sublevel production b LTCC and sublevel production with pillar c conventional longwall and sublevel production

Table 9 Parameter descriptions in the method

\begin{tabular}{llll}
\hline Parameter & Description & Parameter & Description \\
\hline$h_{\mathrm{t}}(\mathrm{m})$ & Coal cutting height & $L_{2}(\mathrm{~m})$ & Immediate roof upper boundary length \\
$h_{\mathrm{c}}(\mathrm{m})$ & Top coal height & $L_{1}(\mathrm{~m})$ & Top coal upper boundary length \\
$h_{\mathrm{i}}(\mathrm{m})$ & Immediate roof height & $\gamma\left(\mathrm{kN} / \mathrm{m}^{3}\right)$ & Immediate roof unit volume weight \\
$B$ & Bulking factor & $W_{\mathrm{i}}$ & Immediate roof block weight \\
$B_{\mathrm{c}}$ & Coal bulking factor & $n$ & Safety factor \\
$l_{\mathrm{c}}$ & Top coal loose rate & $S_{\mathrm{c}}$ & Distance between center of two shields \\
$W_{\mathrm{t}}$ & Top coal block weight & $\gamma_{\mathrm{c}}\left(\mathrm{kN} / \mathrm{m}^{3}\right)$ & Coal unit volume weight \\
$L(\mathrm{~m})$ & Working length in face & Req. Be $\left(\mathrm{kN} / \mathrm{m}^{3}\right)$ & Floor required bearing capacity \\
$Q(\mathrm{kN})$ & Support capacity & Av. Be $\left(\mathrm{kN} / \mathrm{m}^{3}\right)$ & Floor available bearing capacity \\
$L_{3}(\mathrm{~m})$ & Support shield base length & & \\
\hline
\end{tabular}

studied again and the results are presented in Table 14. According to the bearing capacity of the floor for both coal and claystone, the available height can be changed from 2 to $4 \mathrm{~m}$ as per the analyses.

\subsection{Hydraulic shield support and floor bearing capacity for seam-C}

Seam-C thickness varies between $2.5 \mathrm{~m}$ and $4 \mathrm{~m}$ roof and floor strata forms by sandstone and claystone. Conventional mechanized longwall mining method, which is also the combined system of hydraulic shields, AFC conveyor, and shearer, designed for seam-C. Roof strata is classified similarly as seam-A and it is classified as high cavability. Floor material that is mostly claystone has different compressive strengths from 0.3 to $34.5 \mathrm{MPa}$ and the average strength is $5.1 \mathrm{MPa}$. Detached roof method was also applied for the design and the results are presented in Table 15.

\subsection{Evaluations and discussions}

Different production alternatives were investigated for mechanized longwall design in seam-A and seam-C. The outputs of the design studies were discussed below.

Sublevels, which are also called as slices in a longwall panel, are projected in seam-A. The LTCC method was implemented in different alternatives for the production. The average compressive strength of lignite and floor claystone is $3.4 \mathrm{MPa}$ and $5.5 \mathrm{MPa}$, respectively. The 
Table 10 Parameter values applied in the method (Jangara et al. 2018)

\begin{tabular}{ll}
\hline Parameter & Value \\
\hline SAR claystone bulking factor & 1.3 \\
Lignite bulking factor & 1.4 \\
Sandstone bulking factor & 1.3 \\
Immediate roof falling angel $\left({ }^{\circ}\right)$ & 10 \\
Top coal falling angel $\left(^{\circ}\right)$ & 20 \\
Sandstone unit weight $\left(\mathrm{kN} / \mathrm{m}^{3}\right)$ & 21.81 \\
SAR claystone unit volume weight $\left(\mathrm{kN} / \mathrm{m}^{3}\right)$ & 20.04 \\
Coal unit volume weight $\left(\mathrm{kN} / \mathrm{m}^{3}\right)$ & 15.2 \\
Top coal loose rate & $20 \%$ \\
Safety factor & 2.0 \\
\hline
\end{tabular}

Table 11 LTCC working face parameters (Jangara et al. 2018)

\begin{tabular}{ll}
\hline Parameter & Value $(\mathrm{m})$ \\
\hline Shield support distance $\left(S_{\mathrm{S}}\right)$ & 1.6 \\
Shield base length $\left(L_{3}\right)$ & 3.0 \\
Shield canopy length & 5.0 \\
Width of cut $\left(W_{\mathrm{eb}}\right)$ & 0.8 \\
Tip to face & 0.8 \\
Rear overhang & 0.0 \\
\hline
\end{tabular}

maximum height of one slice is $6 \mathrm{~m}$ where cutting height $2 \mathrm{~m}$, and top coal height is $4 \mathrm{~m}$. The total height of the third slice where the floor is claystone can be $10 \mathrm{~m}$, and the cutting height is $3 \mathrm{~m}$. Hence, the total producible thickness for Seam-A reaches up to $22 \mathrm{~m}$ in three slices. The second alternative is to leave the pillar in the upper slice to decrease the weight on the hydraulic shields. The results are similar for the second production alternative in seam-A. The only difference is the cutting height that can be increased to $3 \mathrm{~m}$ for the sublevels in lignite where the maximum height of the slice can be $6 \mathrm{~m}$. Similarly, the maximum height is $10 \mathrm{~m}$ and the cutting height can be taken up to $3.5 \mathrm{~m}$ and the top coal is $6.5 \mathrm{~m}$ high for the third slice. This application will decrease the amount of production loss. Finally, the application of conventional mechanized longwall mining results as the third alternative show that the mining height can be taken up to $4 \mathrm{~m}$, and three sublevels can be projected up to $12 \mathrm{~m}$ coal thickness.

The same procedure was applied for seam-C. The producible thickness can be design as $4 \mathrm{~m}$ by conventional mechanized longwall mining method based on the average floor bearing capacity, which is $5.1 \mathrm{MPa}$.

Recovery rate of top coal limits the applicability of fully mechanized production in longwall mining in terms of economic aspects. Higher strength of coal and surrounding strata increases the recovery rate however, it is very low in this case, so the recovery rate of top coal will be low. Resource modelling and mine design and planning studies should be considered based on the geotechnical properties and the low rate for recovery especially leaving pillar for strength requirement needs to be taken care of. The very low strength of the strata also limits applicability of different drawing and cutting alternatives in the longwall. It's clear that one advance and one drawing alternative should be the most suitable one for LTCC production alternative as proposed by Wang et al. (2015).

The ground condition for all seams' floor in the study area is in very low bearing capacity. The design was performed based on the average value of floor material compressive strength, however, the value was sometimes very low or the material was classified as the soil in some locations. Thus, geotechnical conditions were assumed as the weakest link for the site and once the production panel was projected and a geotechnical study must be conducted to understand the distribution of floor bearing capacity for the applicability of mechanized mining. This application should be applied for the entire production schedule at Alpu lignite field. Therefore, the amount of reserve that is defined as the producible amount of mine resource is totally related to the ground stability of coal seams for the project site. Mine design and planning works should follow the geotechnical researches. Geo-spatial distribution of floor bearing capacity and roof strength for strata surrounding coal seams should be modelled prior to mine planning for the coal mine site similar with Alpu in terms of geotechnical properties. The longwall mine design will be projected based on the output of the research.

\section{Numerical analyses for ground control}

Floor bearing capacity and caving behavior of the roof strata are critical due to the very low strength in the study area. Similarly, wall failure and/or face spalling can be the other issues during the working of mechanized longwall machinery. Any failure will cause wasting time, injuries, or machine failures. 2D finite element method was performed as numerical analysis to understand the reliability of cutting heights proposed by analytical solutions. Different cutting heights were applied to understand the wall and face stability.

Mohr-Coulomb failure envelope is defined as failure criteria due to the low strength of lignite and surrounding strata. Vertical stress $\left(\sigma_{\mathrm{v}}\right)$ for in-situ stress conditions is directly estimated from the overburden height that is a function of unit volume weight and depth. Hence, it is calculated as $0.21 \mathrm{H}$ in $\mathrm{MPa}$ according to Eq. (3). 
(a) LTCC and sublevel production

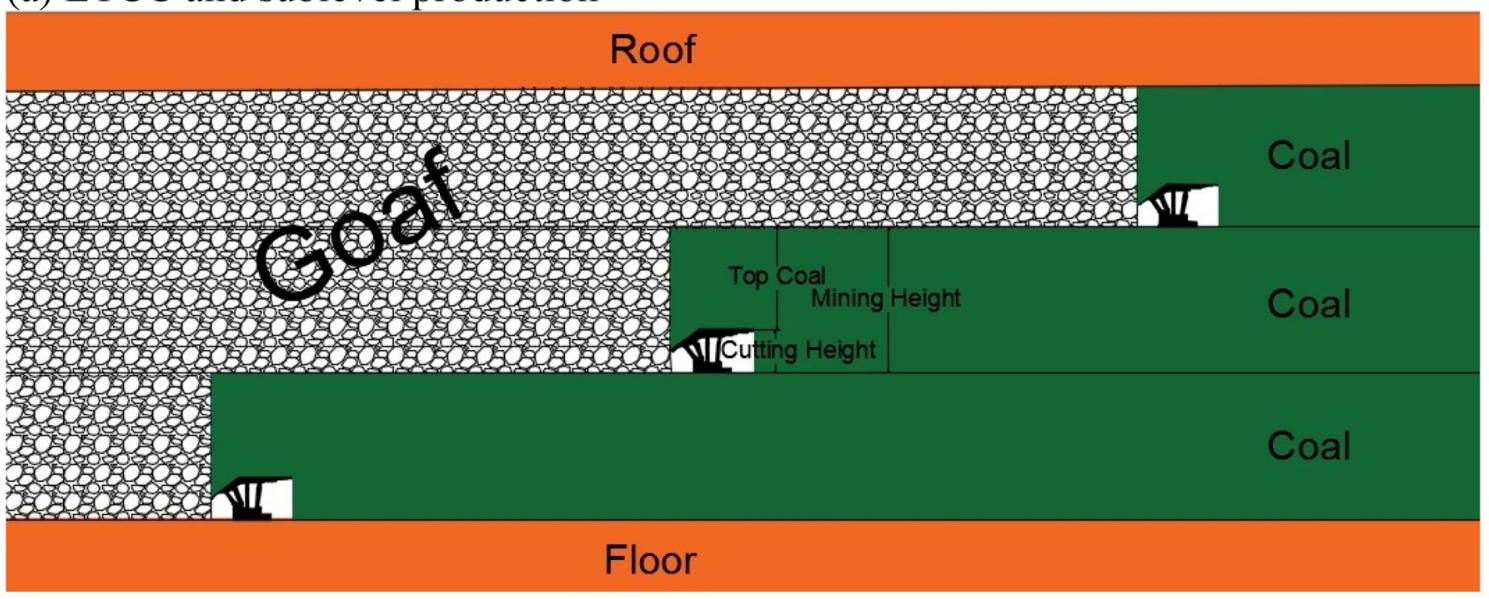

(b) LTCC and sublevel production with pillar

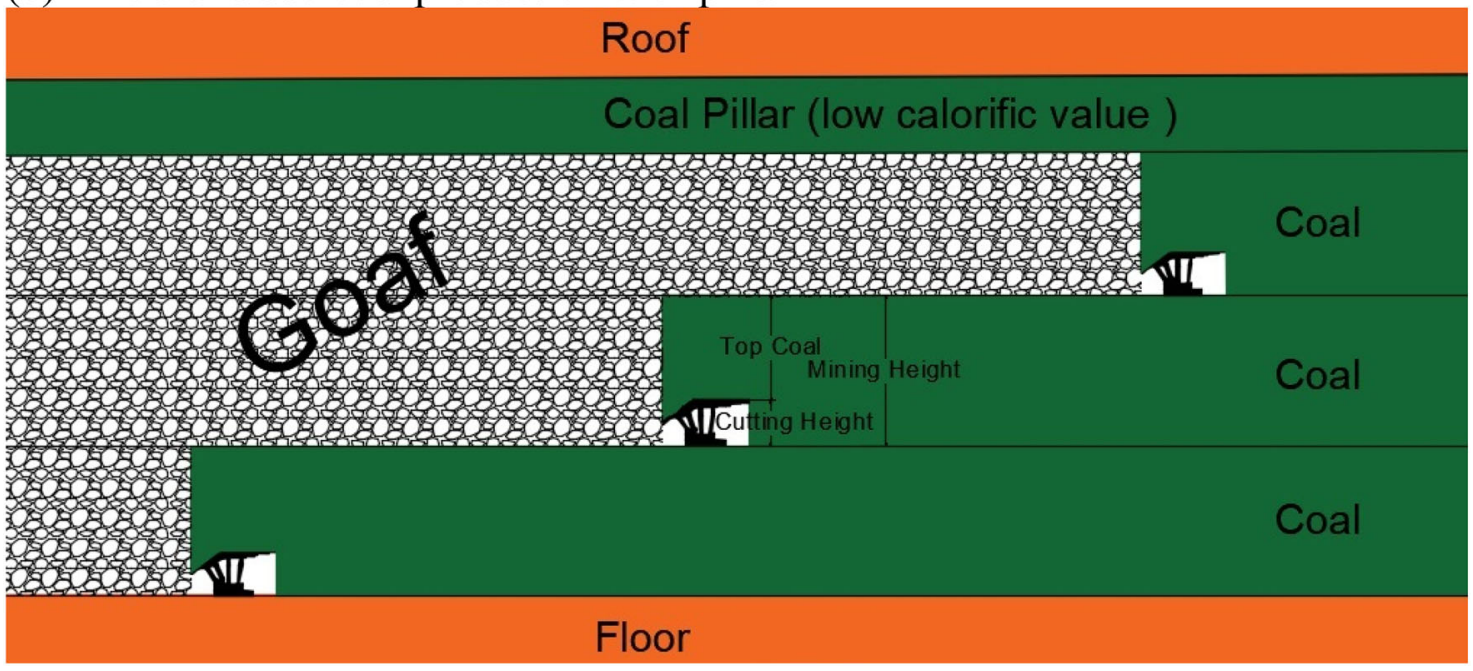

(c) Conventional longwall and sublevel production

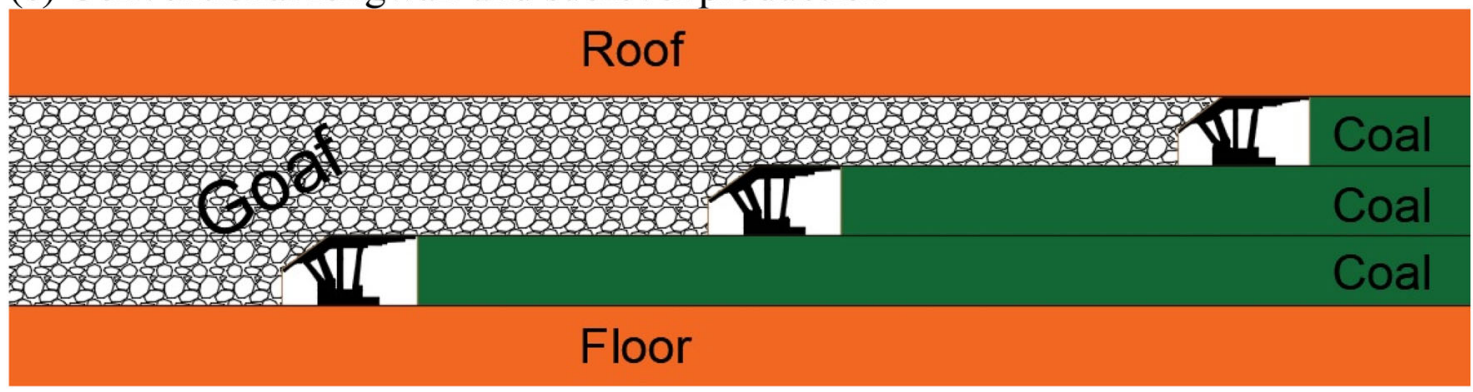

Fig. 5 Production alternatives for seam-A (Jangara 2017)

Horizontal stress $\left(\sigma_{\mathrm{h}}\right)$ was assumed as equal with vertical stress due to the low strength material (Brown and Hoek 1978; Wilson 1983).

$\sigma_{\gamma}=\gamma H($ in $\mathrm{MPa})$

The complex hydrogeological structure and dewatering solutions have been studied for the mine site. The scope of dewatering studies to lower the underwater level below the mining level. Underground water level would be reduced below the mining level and numerical model was compute in dry condition according to the field and hydrogeological conditions as well as existing studies. Material properties were used in the numerical models are taken from the geotechnical database (Table 2). Goaf material properties 
Table 12 Required shield and floor bearing capacity in sublevel LTCC for different mining height, Seam-A (Jangara 2017)

\begin{tabular}{|c|c|c|c|c|c|c|c|c|}
\hline $\begin{array}{l}\text { Mining } \\
\text { height } \\
(\mathrm{m})\end{array}$ & $\begin{array}{l}\text { Immediate } \\
\text { roof height } \\
\text { (m) }\end{array}$ & $\begin{array}{l}\text { Cutting } \\
\text { height } \\
(\mathrm{m})\end{array}$ & $\begin{array}{l}\text { Top } \\
\text { coal } \\
\text { height } \\
\text { (m) }\end{array}$ & $\begin{array}{l}\text { Detached } \\
\text { roof weight } \\
(\mathrm{kN})\end{array}$ & $\begin{array}{l}\text { Shield } \\
\text { capacity } \\
(\mathrm{kN})\end{array}$ & $\begin{array}{l}\text { Average required bearing } \\
\text { capacity at the base } \\
(\mathrm{MPa})\end{array}$ & $\begin{array}{l}\text { Maximum required } \\
\text { bearing capacity at the } \\
\text { base } \\
(\mathrm{MPa})\end{array}$ & $\begin{array}{l}\text { Available } \\
\text { bearing } \\
\text { capacity } \\
(\mathrm{MPa})\end{array}$ \\
\hline \multirow[t]{7}{*}{5} & 13.9 & 2.00 & 3.00 & 3434 & 6869 & 1.43 & 2.86 & \multirow[t]{7}{*}{3.4} \\
\hline & 14.1 & 2.25 & 2.75 & 3501 & 7003 & 1.46 & 2.92 & \\
\hline & 14.3 & 2.50 & 2.50 & 3569 & 7139 & 1.49 & 2.97 & \\
\hline & 14.6 & 2.75 & 2.25 & 3639 & 7277 & 1.52 & 3.03 & \\
\hline & 14.8 & 3.00 & 2.00 & 3709 & 7418 & 1.55 & 3.09 & \\
\hline & 15.0 & 3.25 & 1.75 & 3781 & 7561 & 1.58 & 3.15 & \\
\hline & 15.3 & 3.50 & 1.50 & 3853 & 7706 & 1.61 & 3.21 & \\
\hline \multirow[t]{7}{*}{6} & 16.5 & 2.00 & 4.00 & 4071 & 8142 & 1.70 & 3.39 & \multirow[t]{7}{*}{3.4} \\
\hline & 16.8 & 2.25 & 3.75 & 4144 & 8289 & 1.73 & 3.45 & \\
\hline & 17.0 & 2.50 & 3.50 & 4219 & 8438 & 1.76 & 3.52 & \\
\hline & 17.2 & 2.75 & 3.25 & 4294 & 8588 & 1.79 & 3.58 & \\
\hline & 17.4 & 3.00 & 3.00 & 4371 & 8741 & 1.82 & 3.64 & \\
\hline & 17.6 & 3.25 & 2.75 & 4448 & 8896 & 1.85 & 3.71 & \\
\hline & 17.8 & 3.50 & 2.50 & 4526 & 9053 & 1.89 & 3.77 & \\
\hline \multirow[t]{7}{*}{10} & 26.4 & 2.00 & 8.00 & 6093 & 12186 & 2.54 & 5.08 & \multirow[t]{7}{*}{5.5} \\
\hline & 26.6 & 2.25 & 7.75 & 6206 & 12412 & 2.59 & 5.17 & \\
\hline & 26.8 & 2.50 & 7.50 & 6320 & 12640 & 2.63 & 5.27 & \\
\hline & 27.1 & 2.75 & 7.25 & 6435 & 12870 & 2.68 & 5.36 & \\
\hline & 27.3 & 3.00 & 7.00 & 6551 & 13102 & 2.73 & 5.46 & \\
\hline & 27.5 & 3.25 & 6.75 & 6668 & 13336 & 2.78 & 5.56 & \\
\hline & 27.7 & 3.50 & 6.50 & 6786 & 13572 & 2.83 & 5.66 & \\
\hline
\end{tabular}

were estimated from previous researches due to the unavailability of test material or in-situ testing during prefeasibility studies. In order to represent field conditions, goaf properties should be simulated based on the vertical stresses on the goaf material to gain the precise results (Banerjee et al. 2015). Elastic properties of the goaf is also a function of time and experimental results can be characterized according to Eq. (4) (Xie et al. 1999).

$E=15+175\left(1-\mathrm{e}^{-1.25 \mathrm{t}}\right)$

Yasitli and Unver (2005) used goaf Poisson's ratio as 0.495 for the Tuncbilek lignite field while Yavuz (2004) defined unit volume weight as $0.017 \mathrm{MN} / \mathrm{m}^{3}$. Singh and Singh (2011) used unit volume weight as $0.018 \mathrm{MN} / \mathrm{m}^{3}$ and friction angle as $25^{\circ}$ for goaf. Table 16 was prepared to present the goaf properties used in numerical analyses.

RS2 software was used to simulate the condition of the mechanized longwall for the LTCC method. Stresses, strength factors and yielded elements were taken as output of the analyses. The boundary conditions were fixed at zero. One of the finite element model was presented in Fig. 6. The mesh system was used for finite elements. Automatic mesh around the longwall was generated to model deformations and stresses that were derived from elastoplastic analyses. Numerical analyses were performed under these conditions. Normal $\left(\sigma_{1}\right)$ and horizontal stresses $\left(\sigma_{3}\right)$, strength factor (SF), and yielded elements were determined after a series of iterations of modeling studies. $\mathrm{SF}$ is the ratio between rock strength to induce stress that presents the adequate support systems. Stresses were investigated the effect of longwall height while SF can be used to understand caving conditions as well as stability conditions around the openings. Yielded elements were used to calculate the yielded distance through the face to understand the unsupported roof availability for the longwall. Four different cutting heights were modeled in the analyses that are 2.0, 2.5, 3.0, and $3.5 \mathrm{~m}$, respectively. Top coal excavation was performed by caving from the rear of the longwall from hydraulic shields. The outputs of the numerical analyses, are presented in Fig. 7 for normal stress distribution, Fig. 8 for horizontal stress distribution, Fig. 9 for strength factor, and Fig. 10 for yielded elements.

In-situ stress, stress in caving zone at the rear of the shield, and stress in the cutting zone at the front of the shield can be compared from the normal stress numerical models. In-situ stress is quite similar with the virgin in-situ 
Table 13 Required shield and floor bearing capacity in sublevel LTCC with a pillar for different mining height, Seam-A (Jangara 2017)

\begin{tabular}{|c|c|c|c|c|c|c|c|c|}
\hline $\begin{array}{l}\text { Mining } \\
\text { height } \\
\text { (m) }\end{array}$ & $\begin{array}{l}\text { Immediate } \\
\text { roof height } \\
\text { (m) }\end{array}$ & $\begin{array}{l}\text { Cutting } \\
\text { height } \\
(\mathrm{m})\end{array}$ & $\begin{array}{l}\text { Top } \\
\text { coal } \\
\text { height } \\
\text { (m) }\end{array}$ & $\begin{array}{l}\text { Detached } \\
\text { roof weight } \\
(\mathrm{kN})\end{array}$ & $\begin{array}{l}\text { Shield } \\
\text { capacity } \\
(\mathrm{kN})\end{array}$ & $\begin{array}{l}\text { Average required } \\
\text { bearing capacity at the } \\
\text { base } \\
(\mathrm{MPa})\end{array}$ & $\begin{array}{l}\text { Maximum required } \\
\text { bearing capacity at the } \\
\text { base } \\
(\mathrm{MPa})\end{array}$ & $\begin{array}{l}\text { Available } \\
\text { bearing } \\
\text { capacity } \\
(\mathrm{MPa})\end{array}$ \\
\hline \multirow[t]{7}{*}{5} & 13.9 & 2.00 & 3.00 & 3174 & 6347 & 1.32 & 2.64 & \multirow[t]{7}{*}{3.4} \\
\hline & 14.1 & 2.25 & 2.75 & 3236 & 6473 & 1.35 & 2.70 & \\
\hline & 14.3 & 2.50 & 2.50 & 3300 & 6600 & 1.38 & 2.75 & \\
\hline & 14.6 & 2.75 & 2.25 & 3365 & 6730 & 1.40 & 2.80 & \\
\hline & 14.8 & 3.00 & 2.00 & 3431 & 6862 & 1.43 & 2.86 & \\
\hline & 15.0 & 3.25 & 1.75 & 3498 & 6997 & 1.46 & 2.92 & \\
\hline & 15.3 & 3.50 & 1.50 & 3567 & 7133 & 1.49 & 2.97 & \\
\hline \multirow[t]{7}{*}{6} & 16.3 & 2.00 & 4.00 & 3748 & 7495 & 1.56 & 3.12 & \multirow[t]{7}{*}{3.4} \\
\hline & 16.5 & 2.25 & 3.75 & 3820 & 7640 & 1.59 & 3.18 & \\
\hline & 16.7 & 2.50 & 3.50 & 3893 & 7787 & 1.62 & 3.24 & \\
\hline & 17.0 & 2.75 & 3.25 & 3968 & 7936 & 1.65 & 3.31 & \\
\hline & 17.2 & 3.00 & 3.00 & 4044 & 8087 & 1.68 & 3.37 & \\
\hline & 17.4 & 3.25 & 2.75 & 4121 & 8241 & 1.72 & 3.43 & \\
\hline & 17.7 & 3.50 & 2.50 & 4199 & 8397 & 1.75 & 3.50 & \\
\hline \multirow[t]{7}{*}{10} & 25.9 & 2.00 & 8.00 & 5720 & 11440 & 2.38 & 4.77 & \multirow[t]{7}{*}{5.5} \\
\hline & 26.1 & 2.25 & 7.75 & 5831 & 11662 & 2.43 & 4.86 & \\
\hline & 26.3 & 2.50 & 7.50 & 5943 & 11886 & 2.48 & 4.95 & \\
\hline & 26.6 & 2.75 & 7.25 & 6056 & 12113 & 2.52 & 5.05 & \\
\hline & 26.8 & 3.00 & 7.00 & 6171 & 12342 & 2.57 & 5.14 & \\
\hline & 27.0 & 3.25 & 6.75 & 6286 & 12573 & 2.62 & 5.24 & \\
\hline & 27.3 & 3.50 & 6.50 & 6403 & 12806 & 2.67 & 5.34 & \\
\hline
\end{tabular}

Table 14 Required shield and floor bearing capacity in sublevel longwall, Seam-A (Jangara 2017)

\begin{tabular}{lllllll}
\hline $\begin{array}{l}\text { Immediate } \\
\text { roof height } \\
(\mathrm{m})\end{array}$ & $\begin{array}{l}\text { Mining } \\
\text { height } \\
(\mathrm{m})\end{array}$ & $\begin{array}{l}\text { Detached roof } \\
\text { weight } \\
(\mathrm{kN})\end{array}$ & $\begin{array}{l}\text { Shield } \\
\text { capacity } \\
(\mathrm{kN})\end{array}$ & $\begin{array}{l}\text { Average required bearing } \\
\text { capacity at the base } \\
(\mathrm{MPa})\end{array}$ & $\begin{array}{l}\text { Maximum required bearing } \\
\text { capacity at the base } \\
(\mathrm{MPa})\end{array}$ & $\begin{array}{l}\text { Available bearing } \\
\text { capacity } \\
(\mathrm{MPa})\end{array}$ \\
\hline 6.7 & 2.0 & 1536 & 3073 & 0.64 & 1.28 \\
8.3 & 2.5 & 1960 & 3920 & 0.82 & 1.63 \\
10.0 & 3.0 & 2399 & 4798 & 1.00 & 2.00 \\
11.7 & 3.5 & 2854 & 5707 & 1.19 & 2.38 \\
13.3 & 4.0 & 3324 & 6648 & 1.39 & 2.77 \\
\hline
\end{tabular}

Table 15 Required shield and floor bearing capacity in different cutting height, seam-C (Jangara 2017)

\begin{tabular}{lllllll}
\hline $\begin{array}{l}\text { Immediate } \\
\text { roof height } \\
(\mathrm{m})\end{array}$ & $\begin{array}{l}\text { Mining } \\
\text { height } \\
(\mathrm{m})\end{array}$ & $\begin{array}{l}\text { Detached roof } \\
\text { weight } \\
(\mathrm{kN})\end{array}$ & $\begin{array}{l}\text { Shield } \\
\text { capacity } \\
(\mathrm{kN})\end{array}$ & $\begin{array}{l}\text { Average required bearing } \\
\text { capacity at the base } \\
(\mathrm{MPa})\end{array}$ & $\begin{array}{l}\text { Maximum required bearing } \\
\text { capacity at the base } \\
(\mathrm{MPa})\end{array}$ & $\begin{array}{l}\text { Available bearing } \\
\text { capacity } \\
(\mathrm{MPa})\end{array}$ \\
\hline 6.7 & 2 & 1672 & 3344 & 0.70 & 1.39 \\
8.3 & 2.5 & 2133 & 4266 & 0.89 & 1.78 \\
10.0 & 3 & 2611 & 5222 & 1.09 & 2.18 \\
11.7 & 3.5 & 3106 & 6211 & 1.29 & 2.59 \\
13.3 & 4 & 3618 & 7236 & 1.51 & 3.01 \\
\hline
\end{tabular}


Table 16 Goaf properties in numerical models

\begin{tabular}{|c|c|c|c|c|c|c|c|c|}
\hline \multirow{2}{*}{$\begin{array}{l}\text { Unit volume weight } \\
\left(\mathrm{MN} / \mathrm{m}^{3}\right)\end{array}$} & \multirow{2}{*}{$\begin{array}{l}\text { Cohesion } \\
(\mathrm{MPa})\end{array}$} & \multirow{2}{*}{$\begin{array}{l}\text { Friction angel } \\
\left({ }^{\circ}\right)\end{array}$} & \multirow{2}{*}{$\begin{array}{l}\text { Indirect tensile strength } \\
(\mathrm{MPa})\end{array}$} & \multirow[t]{2}{*}{ Poisson ratio } & \multicolumn{4}{|c|}{ Modulus of elasticity } \\
\hline & & & & & Day 1 & Day 2 & Day 3 & Final \\
\hline 0.017 & 0.001 & 25 & 0 & 0.495 & 140 & 176 & 186 & 190 \\
\hline
\end{tabular}

stress calculated by the Eq. (3) and it is around $8 \mathrm{MPa}$. Stress in at the front reaches $24 \mathrm{MPa}$ while it is around $3 \mathrm{MPa}$. The increasing cutting height results in the increasing amount of stresses for both normal and horizontal stresses. Increasing horizontal stress will cause working face instability that limits cutting heights. Caving conditions can easily be seen in the strength factor distribution for each cutting heights. The SF values were scattered around 1.0 roof and faced of the longwall for each cutting height. Most critical outputs determined from the analyses that are the yielded elements and the yielded depths, which can be seen in Fig. 10. The depth was

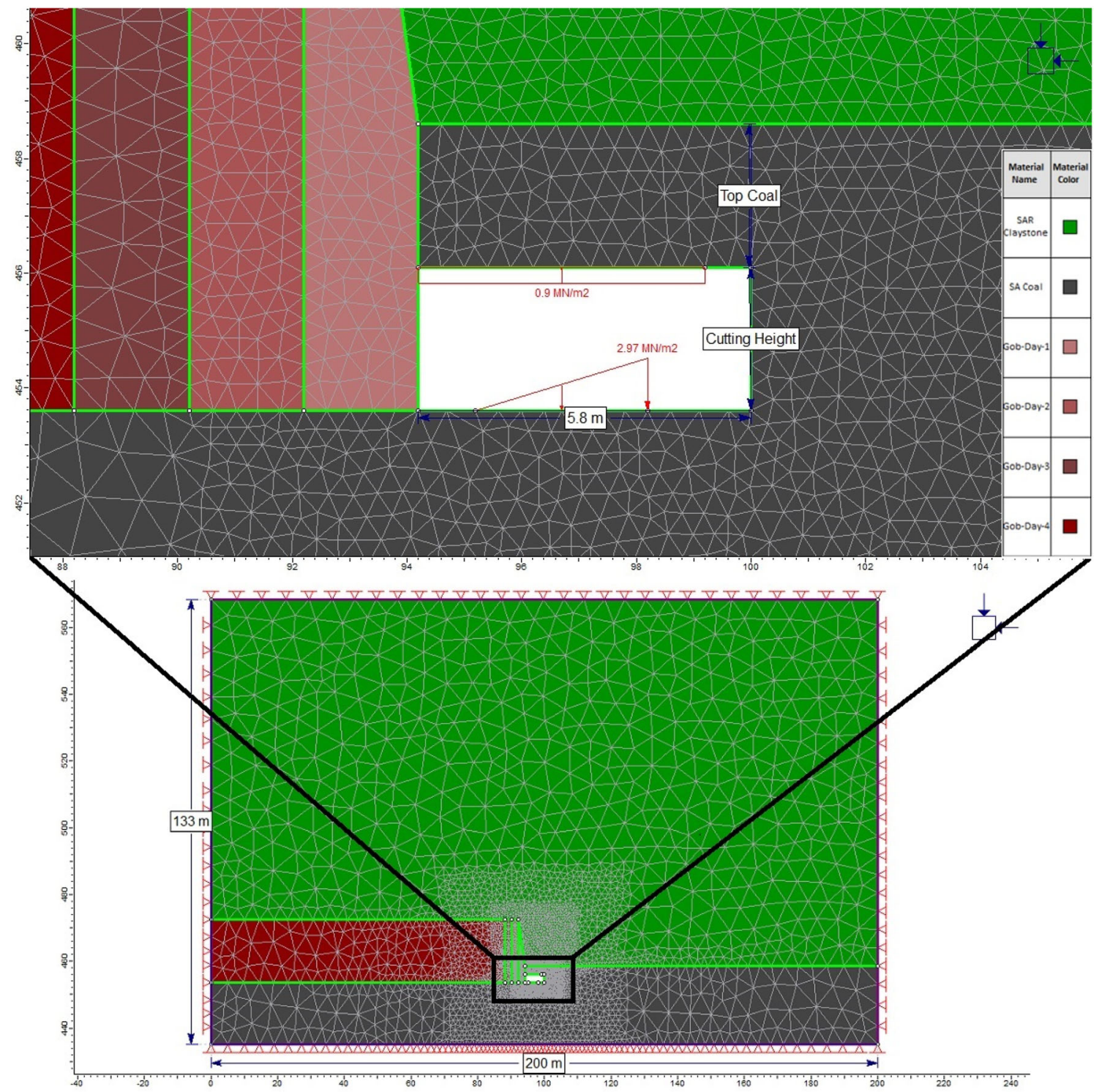

Fig. 6 Finite elemet model layout and boundary conditions 


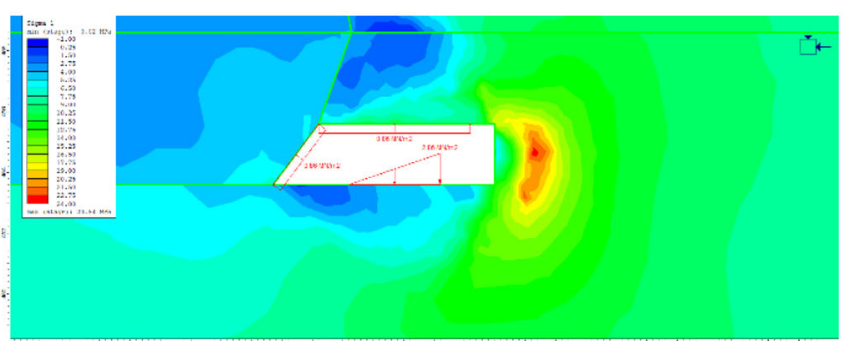

Cutting Height: 2 m

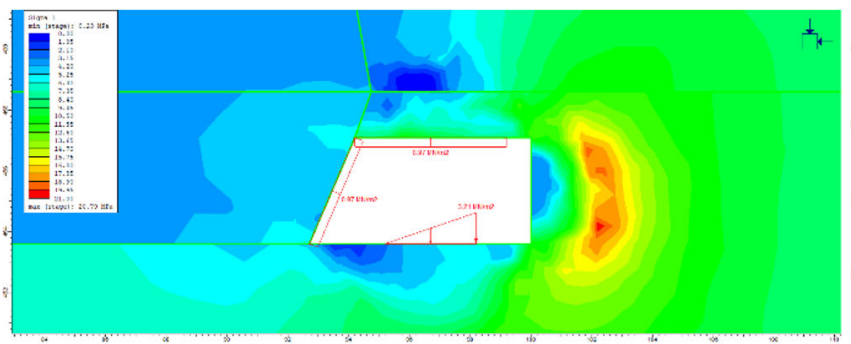

Cutting Height: 3 m

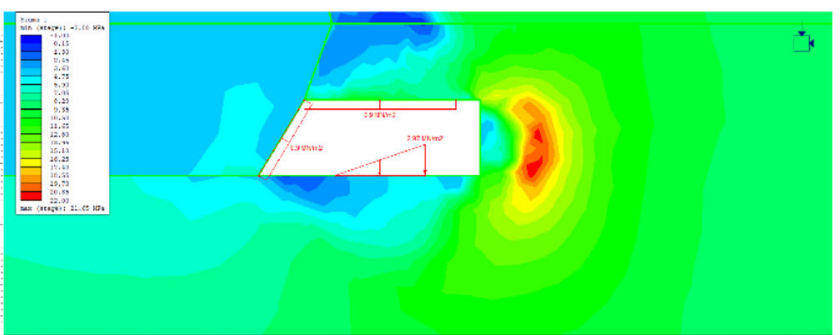

Cutting Height:" $2.5 \mathrm{~m}$

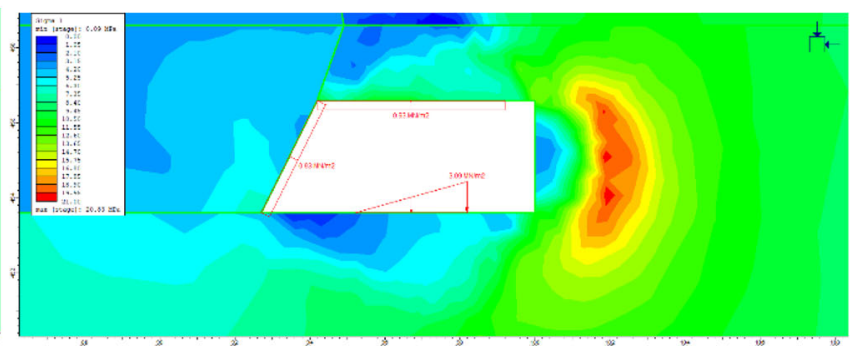

Cutting Height: $3.5 \mathrm{~m}$

Fig. 7 Normal stress numerical model output for different cutting heights

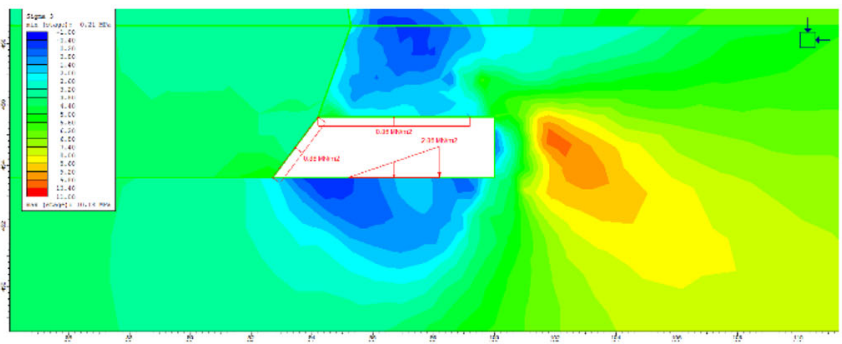

Cutting Height: 2 m

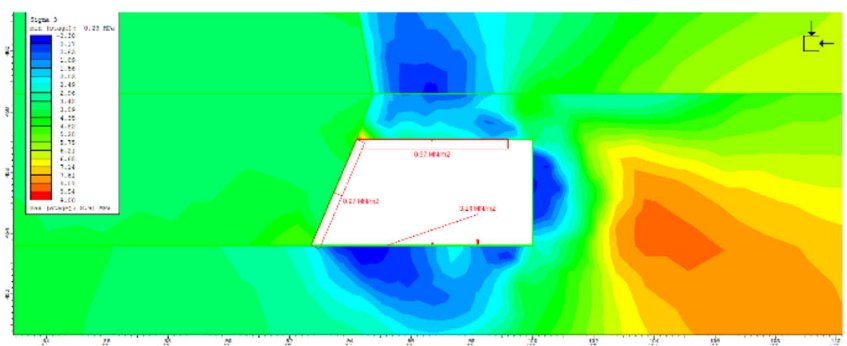

Cutting Height: 3 m

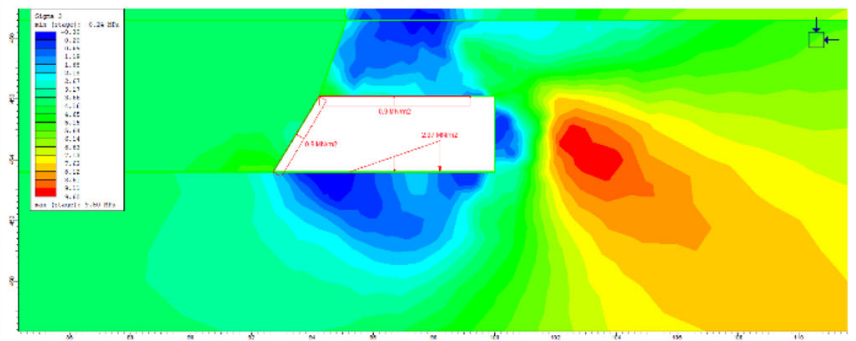

Cutting Height: $2.5 \mathrm{~m}$

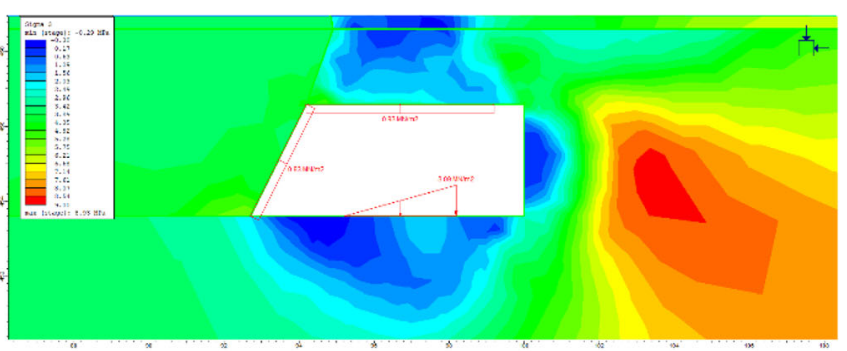

Cutting Height: $3.5 \mathrm{~m}$

Fig. 8 Horizontal stress numerical model output for different cutting heights

increased from $1.4 \mathrm{~m}$ to $2.5 \mathrm{~m}$ by the increasing value of cutting height. Unsupported span was taken as $0.80 \mathrm{~m}$ that is the width of a typical shearer. Once the shearer cut the face, hydraulic shields should be advanced as early as possible to protect the longwall face against roof failure. The increasing value of yielded depth is also critical for face failure. It is recommended to limit deeper spalling in the longwall face related to the daily advance rate. The daily advance rate is taken as 2.0 so the cutting height that can be $3.0 \mathrm{~m}$ according to the yielded element results.
The evaluation of analytical and numerical analyses' results presented in Table 12 recommend that if the cutting height is taken as $3.0 \mathrm{~m}$, the top coal height can be $2.0 \mathrm{~m}$ for the first LTCC production alternative due to the bearing capacity. If the second alternative will be chosen for the production that is leaving pillar in the upper part of the seam, the cutting and the top coal heights can be selected as $3.0 \mathrm{~m}$. 


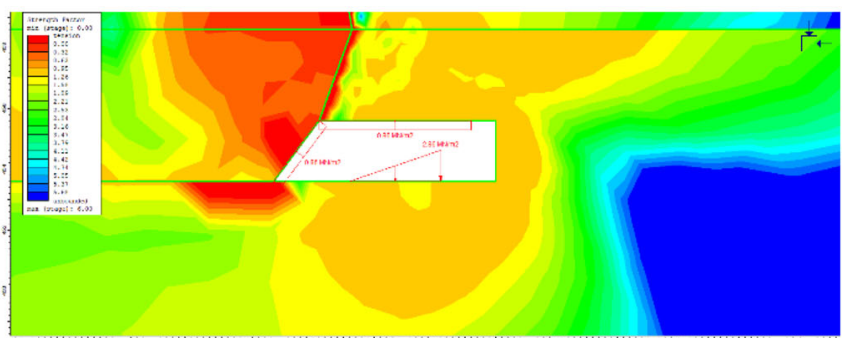

Cutting Height: 2 m

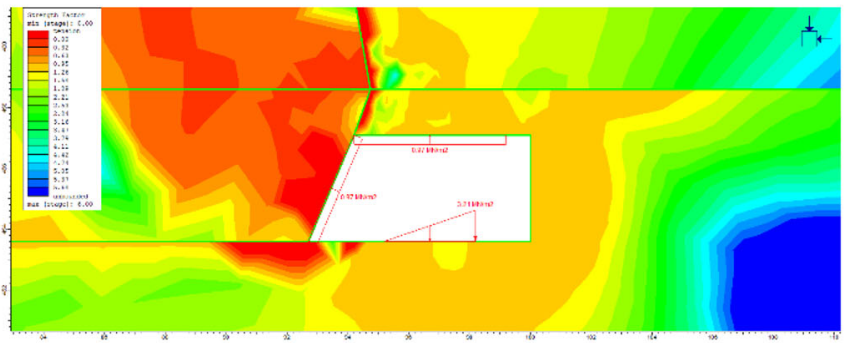

Cutting Height: 3 m

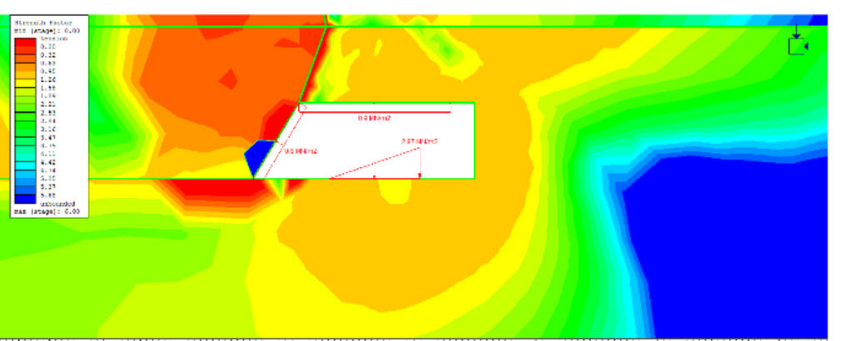

Cutting Height: $2.5 \mathrm{~m}$

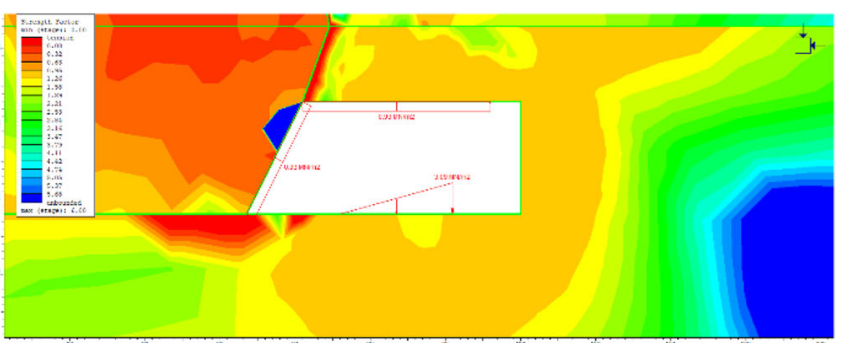

Cutting Height: 3.5 m

Fig. 9 Strength factor numerical model output for different cutting heights

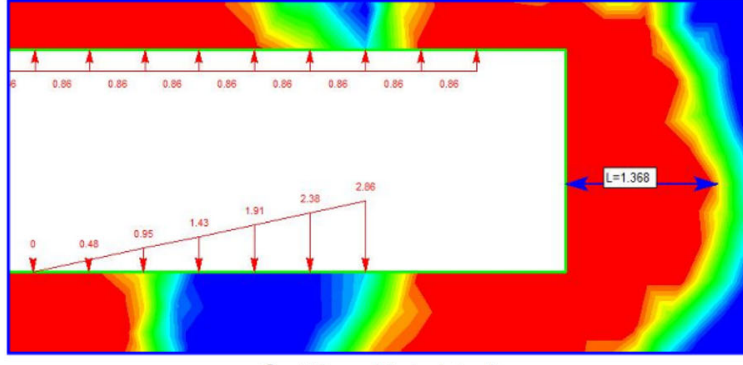

Cutting Height: 2 m

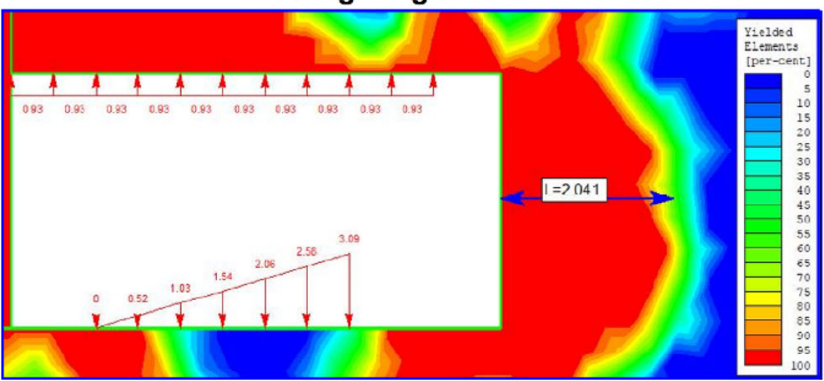

Cutting Height: 3 m

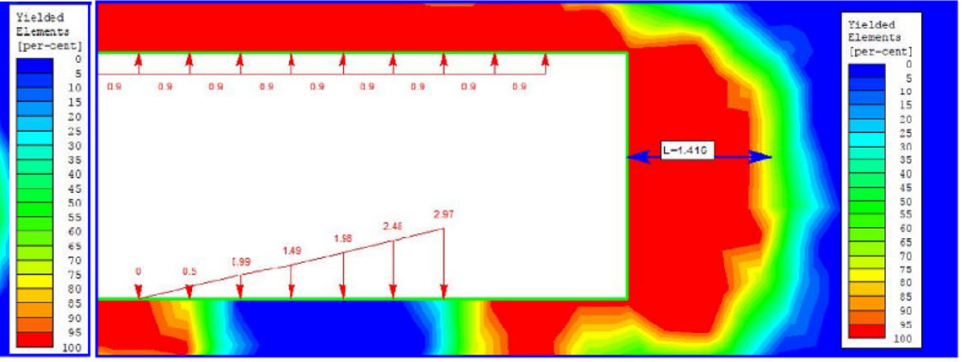

Cutting Height: $2.5 \mathrm{~m}$

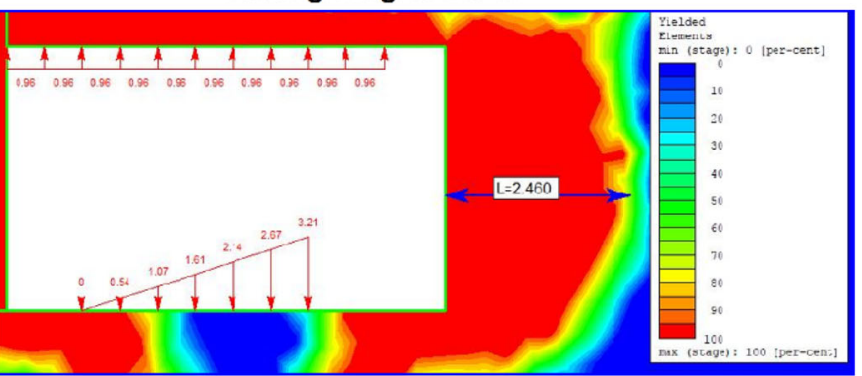

Cutting Height: $3.5 \mathrm{~m}$

Fig. 10 Yielded element numerical model output for different cutting heights

\section{Conclusions}

The Alpu lignite coal field with its two billion tons of resources was investigated with respect to the design of mechanized longwall mining systems. The mine site consists of three coal seams in various thicknesses called as seam-A, seam-B, and seam-C. Seam-A has thickness from 10 to $30 \mathrm{~m}$. The thickness of seam-B is up to $1.5 \mathrm{~m}$ while seam-C thickness reaches to $4 \mathrm{~m}$. According to the feasibility studies, a LTCC mechanized system will be implemented for seam-A, and a conventional mechanized longwall mining system is designed for seam-C. Due to the threshold value of thickness, seam-B is not projected for the production. A comprehensive geotechnical analyses were carried out to understand the strength of coal and surrounding structures. The results increases the importance of geotechnical assessment of mine site for mine planning studies due to the low strength value of roof and floor structures. The following main conclusions were drawn from this study as listed below. 
(1) According to the result of the geotechnical classifications, each lignite seam and surrounding strata were classified as very low classes in terms of strength. Rock mass classification results also revealed the condition. The very low strength of the lignite roof causes an immediate collapse in the rear side that increases the loads on the hydraulic shields. Similarly, very low strength of floor bearing capacity also limits the height of the longwall. The very low strength properties of lignite also create a hazard for roof failure and/or face spalling.

(2) Three different production alternatives were investigated for seam-A. Longwall production will be applied in slices from nearly $30 \mathrm{~m}$ thick lignite in seam-A. The height of each slice, cutting, and top coal heights were designed based on the detached block method for each alternative. Numerical analyses were also performed to understand the face and roof stability during the production in LTCC. If longwall geometries are not implemented based on actual site geotechnical condition and design outputs proposed in this study, the low bearing capacity of floor might result in sinking the machinery and equipment. The low strength of the roof may also cause instability in the roof and face in longwall.

(3) Only one production alternative that is conventional fully mechanized longwall mining was applied for seam-C. Similarly, minimum bearing capacity of floor designated in this study for seam-C for a conventional mechanized longwall mining. If the strata does not meet the required minimum capacities, mechanized longwall mining cannot be applicable.

(4) The primary outcomes of the study present that Alpu lignite field will be the first example that will be designed and implemented in the weakest ground conditions among mechanized longwall mining for both LTCC and conventional mechanized longwall mining.

(5) The bearing capacity of the floor and the strength of the roof can be assumed as the parameter for threshold in reserve estimation. Once the panel location was projected in the mine, geotechnical properties of surrounding strata must be determined from a site and laboratory studies. The mine will be designed for LTCC and mechanized longwall mining in terms of cutting height, daily advance, top coal height, and sublevel heights based on the machinery and equipment specifications. If ground geotechnical features do not meet the minimum required conditions, the resource cannot be accounted for reserve due to the infeasible production. The required bearing capacity for the longwall cutting and top coal heights as well as the daily advance rate can be easily predicted based on the output of the research.

Acknowledgements The paper includes the outputs of the MSc dissertation of Mr. H. Jangara that accomplished for the design of longwall mining systems at Alpu lignite field by the courtesy of Eczacibasi Esan Company, which is the owner of the project site. The authors would like to thank the Company for their support and their consent for the research.

\section{Compliance with ethical standards}

Conflict of interest The authors wish to declare that there are no known conflicts of interest associated with this publication.

Open Access This article is licensed under a Creative Commons Attribution 4.0 International License, which permits use, sharing, adaptation, distribution and reproduction in any medium or format, as long as you give appropriate credit to the original author(s) and the source, provide a link to the Creative Commons licence, and indicate if changes were made. The images or other third party material in this article are included in the article's Creative Commons licence, unless indicated otherwise in a credit line to the material. If material is not included in the article's Creative Commons licence and your intended use is not permitted by statutory regulation or exceeds the permitted use, you will need to obtain permission directly from the copyright holder. To view a copy of this licence, visit http://creativecommons. org/licenses/by/4.0/.

\section{References}

Aghababaei S, Jalalifar H, Saeedi G (2019) Prediction of face advance rate and determination of the operation efficiency in retreat longwall mining panel using rock engineering system. Int J Coal Sci Technol 6(3):419-429

Alehossein H, Poulsen BA (2010) Stress analysis of longwall top coal caving. Int J Rock Mech Min Sci 47(1):30-41

ASTM D4644-16 (2016) Standard Test Method for Slake Durability of Shales and Other Similar Weak Rocks. ASTM International, West Conshohocken

Asutay HJ, Küçükayman A, Gözler Z (1989) The stratigraphy, tectonic setting of Dagkuplu (northern Eskişehir) mélange and petrography of cumulates. Maden Tetkik ve Arama Genel Müdürlügü Bulletin 109:1-6

Banerjee G, Ghosh N, Kumbhakar D, Yadava KP (2015) A method for simulation of longwall goaf. In: 49th US Rock mechanics/geomechanics symposium, San Francisco.

Barczak TM, Tadolini SC (2006) Longwall shield and standing gate road support designs-is bigger better. In: Proceedings of longwall shield and standing gateroad support designs-is bigger better? Pittsburgh, USA

Bieniawski ZT (1976) Rock mass classification of jointed rock masses. In: Proceedings of exploration for rock engineering, Balkema, Johannesburg, p 97-106.

Bieniawski ZT (1989) Engineering rock mass classifications. Wiley, New York

Bilinski A, Konopko W (1973) Criteria of choice and use of powered supports. In: ISRM International symposium, Katowice, Poland.

Brown ET, Hoek E (1978) Trends in relationships between measured in-situ stresses and depth. Int J Rock Mech Min Sci Geomech Abstr 15(4):211-215

Galvin JM (2016) Ground engineering-principles and practices for underground coal mining. Springer, Switzerland 
Gamble JC (1971) Durability-plasticity classification of shales and other argillaceous rocks. Dissertation, University of Illinois at Urbana-Champaign.

Jangara H (2017) Ground control conditions of the mechanized longwall mining at Alpu lignite deposit. Dissertation, Istanbul Technical University.

Jangara H, Ozturk CA, Kaskati MT, Comlek N, Kibar O (2018) Ground control principals for longwall top coal caving mining. In: 10th Asian rock mechanics symposium, Singapore.

Mangal A, Paul PS (2016) Rock mechanical investigation of strata loading characteristics to assess caving and requirement of support resistance in a mechanized powered support longwall face. Int J Min Sci Technol 26(6):1081-1087

Mark C, Molinda GM (2005) The coal mine roof rating (CMRR) - a decade of experience. Int J Coal Geol 64(1-2):85-103

Molinda GM, Mark C, Debasis D (2001) Using the coal mine roof rating (CMRR) to assess roof stability in US coal mines. Journal of Mines Metals and Fuels 49(8-9):314-321

Ofoegbu GI, Read RS, Ferrante F (2008) Bulking factor of rock for underground openings. Center for nuclear waste regulatory analyses, San Antonio

Peng SS (2008) Coal mine ground control. Morgantown, USA

Peng SS (2019) Longwall mining. CRC Press, Balkema

Peng SS, Chiang HS (1982) Roof stability in longwall coal faces. In: 1st International conference on underground stability, Vancouver, Canada pp 295-335.

Senguler I (2013) Geology and stratigraphy of Eskisehir Alpu coal mine site. MTA Doğal Kaynaklar ve Ekonomi Bülteni 16:89-93 (in Turkish)

Singh GSP, Singh UK (2011) Assessment of goaf characteristics and compaction in longwall caving. Min Technol 120(4):222-232

Syd SP (1992) Surface subsidence engineering. Society for Mining Metallurgy. Littleton, Colorado
Toprak S, Sutcu EC, Senguler I (2015) A fault controlled, newly discovered Eskisehir Alpu coal basin in Turkey, its petrographical properties and depositional environment. Int $\mathrm{J}$ Coal Geol 138:127-144

Wang J (2014) Development and prospect on fully mechanized mining in Chinese coal mines. Int $\mathrm{J}$ Coal Sci Technol 1(3):253-260

Wang J, Pang Y (2017) Surrounding rock control theory and longwall mining technology innovation. Int $\mathbf{J}$ Coal SciTechnol 4(4):301-309

Wang J, Yu B, Kang H, Wang G, Mao D, Liang Y, Jiang P (2015) Key technologies and equipment for a fully mechanized top-coal caving operation with a large mining height at ultra-thick coal seams. Int J Coal Sci Technol 2(2):97-161

Wang JH, Huang ZZ, Yu L (2017) Three plies in top coal theory and its application in top coal caving mining for ultra-thick coal seams. J China Coal Soc 4:809-816

Wang J, Wei W, Zhang J (2020) Theoretical description of drawing body shape in an inclined seam with longwall top coal caving mining. Int J Coal Sci Technol 7(1):182-195

Wilson AH (1983) The stability of underground workings in the soft rocks of the coal measures. Int J Min Eng 1:91-187

Xie H, Chen Z, Wang J (1999) Three-dimensional numerical analysis of deformation and failure during top coal caving. Int J Rock Mech Min Sci 36(5):651-658

Yasitli NE, Unver B (2005) 3D numerical modeling of longwall mining with top-coal caving. Int $\mathrm{J}$ Rock Mech Min Sci 42(2):219-235

Yavuz H (2004) An estimation method for cover pressure reestablishment distance and pressure distribution in the goaf of longwall coal mines. Int J Rock Mech Min Sci 41(2):193-205

Yazıcıgil H (2016) Hydrogeological characterization and etude of Esan's Alpu coal mine site, Project Technical Report; Ankara; Turkey, Unpublished (in Turkish). 